\title{
Treasury's Role in Promoting Efficient Cash Management: Evidence from South Africa
}

Prepared By: Donald Maphiri

School of Economics

A Paper Prepared in Partial Fulfilment of Requirements for a Degree of Master of Commerce in Economics

September 1999

Supervisor: Prof. Iraj Abedian

University of Cape Town 
The copyright of this thesis vests in the author. No quotation from it or information derived from it is to be published without full acknowledgement of the source. The thesis is to be used for private study or noncommercial research purposes only.

Published by the University of Cape Town (UCT) in terms of the non-exclusive license granted to UCT by the author. 


\section{Acknowledgements}

The author would like to thank the following persons for their invaluable assistance through the development of various drafts of this study.

Firstly, I would like to thank my supervisor, Prof. Iraj Abedian for giving me unusual attention as well as useful suggestions and comments from the time when this paper was still a proposal through its various drafts. Thanks to Prof. Graham Barr for useful comments on the Econometrics part of the study and Dr. Don Ross for his comments on the Game-theoretic part of it. I would also like to thank Mr. Johan Redelinghys from the Department of Finance for providing me with more than enough information and attention when I was last in Pretoria for data collection. I also thank my colleagues for various comments during the development of the study. Finally, I would like to thank Princess Maseko for giving me moral support during difficult times.

Without their assistance this study would have been impossible.

I thank you all. 


\section{Abstract}

This study examines the efficiency of cash management by the South African Treasury. Given the multitude of instruments used in cash management it is impossible to concentrate on all of them. This study, therefore, focuses on the cash balance and marketable securities as objects of analysis. This necessitates a thorough consideration of the operations and efficiency of the Treasury bill market.

The study makes two major contributions. Firstly, it is shown that there exists a saddle point in the interactions between the Treasury and bidders in the auctions. This is Nash equilibrium, in which no party to the game has an incentive to change the strategy unilaterally, except at a loss. This is thus a Pareto effcienti outcome, with both the Treasury and bidders' positions improved. It is, therefore, argued that there is scope for improving cash management and lowering costs of borrowing. It is noted, however, that there are significant improvements made in the management of the cash balance. Secondly, this paper argues against the view widely held by auction theorists that uniform-price auctions are more susceptible to manipulation and, as such, are revenue-inferior to discriminatory auctions. It demonstrates that uniform-price and discriminatory auctions are equally susceptible to manipulation and should that happen, uniform-price auctions are still revenue-superior. This result is the converse of what is generally believed and is compatible with the view held by Friedman $(1960,1991)$. It is also compatible with empirical evidence that has long been viewed as a puzzle. The study, however, concludes that the view held by Friedman is right, but for the wrong reasons. 


\section{Table of Contents}

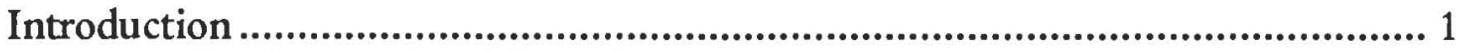

Chapter 1: Background and Overview.................................................................. 5

Problem statement and purpose of study ........................................................5

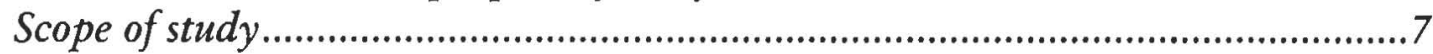

Research methodology ......................................................................................

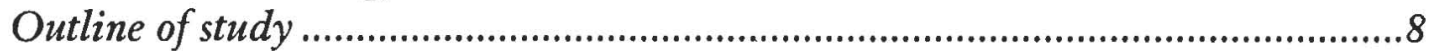

Chapter 2: Review of Theory and Evidence......................................................... 10

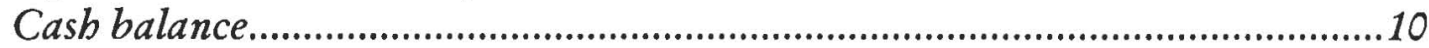

Treasury's securities auction theory ...................................................................11

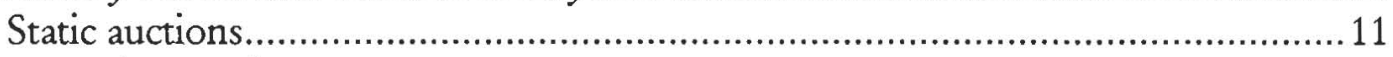

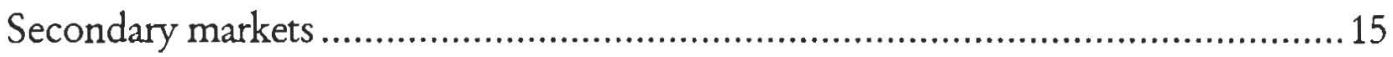

Review of empirical literature ......................................................................17

Chapter 3: Overview of Cash Management Procedures and the Treasury bill

Market in South Africa .......................................................................................25

Cash management procedures ...........................................................................25

The Treasury bill market ………………............................................................27

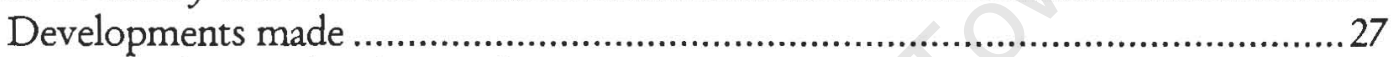

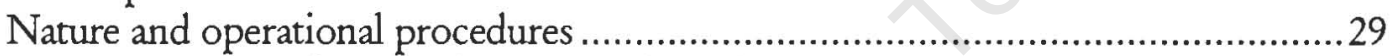

Chapter 4: Data, Analysis and Empirical Findings ................................................35

Management of casb flow ................................................................................35

Marketable securities transactions....................................................................41

Primary market efficiency ................................................................................ 41

Price behaviour in the primary market …………………....................................50

Designing effective auctions: Taxpayers' boon or curse?......................................55

Chapter 5: Implications of Findings for Policy ..................................................60

Cash balance optimisation ...................................................................................60

Market efficiency ...............................................................................................6

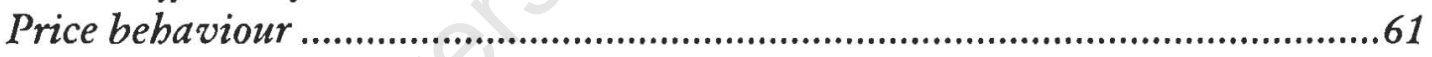

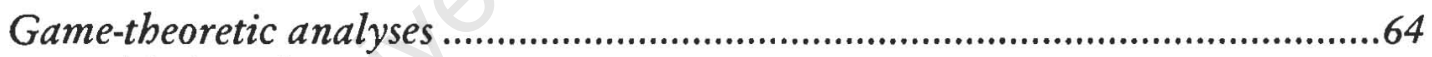

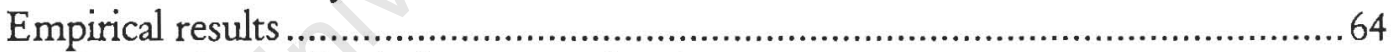

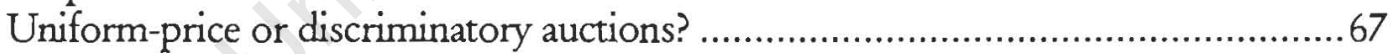

Chapter 6: Conclusion ............................................................................................70

Bibliography .............................................................................................................74

Appendices..................................................................................................................78

Appendix 1: Cash flow structure ...........................................................................78

Appendix 2: Effect of international prices on domestic prices ..............................79

First sub-sample (1980Q2-1989Q4) .................................................................79

Second sub-sample (1990Q1-1998Q4) .......................................................... 80

\section{List of Figures}

Figure 1 : Relations of CPD Treasury bill Holding and Discount Rates (1981-1989) ......32

Figure 2: Relations of CPD Treasury bill Holding and Discount Rates (1989-1998) .......33

Figure 3: Cash Flow Management Chart in South Africa …………………………......36

Figure 4: Government Deposits in PMG Account with the SARB .................................37

Figure 5: Government Deposits with the Reserve Bank ................................................38

Figure 6: Government Deposits with Banks .................................................................38

Figure 7: Cash Flow Requirements for 1998/99 in Rm ..............................................39 
Figure 8: Issuance of Bills to Meet Cash Shortages for 1998/99 in Rm .40

Figure 9: Real Returns on Treasury bills

\section{List of Tables}

Table 1: Comparison of Treasury bill Markets, 1980 - 1989 .......................................28

Table 2: Interest Earned on Tax and Loan Accounts with Banks ................................36

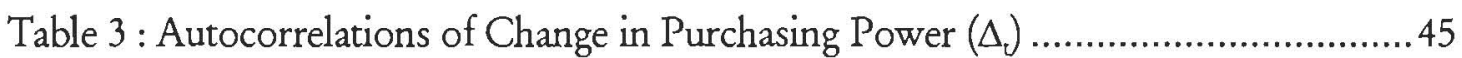

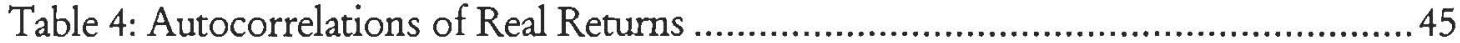

Table 5: Autocorrelations of Change in Nominal Returns ..........................................46

Table 6: Regression of Change in Purchasing Power on Nominal Returns....................47

Table 7: Regression of Change in Purchasing Power on Nominal Returns and Lagged

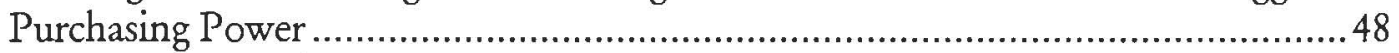

Table 8: Regression of Real Returns on Nominal Returns .......................................49

Table 9: Average Annualised Yield Spreads between Pairs of Adjacent Treasury bills that Mature 1-Week Apart (1981-1998) .....................................................................51

Table 10 : Treasury-Bidders Strategies Payoff Matrix ................................................65 


\section{Introduction}

The way the Treasury markets its securities to finance short-term outlays and debt has serious implications for cash and debt management as well as the costs of borrowing and financing the debt. In 1989, when Chris Stals became the new governor of the South African Reserve Bank (SARB), his main concern was the size of the public debt and the fear that it could get out of hand. In view of that he favoured the strategy of raising interest rates to combat inflation. This was the time when the Bank rate was still an important instrument for monetary policy in South Africa. His actions sent the economy into recession during the early 1990s. This indicates how important the level of the public debt and deficit is in South Africa as a response to global forces.

Growth in public debt in industrialised countries in the 1980 s has intensified policy makers' concerns with implementing effective methods to market government securities. Policy makers have thus considered reforming institutional set-ups of their Treasury bill markets. This is often overlooked in developing and under-developed countries, yet they are countries with higher levels of public debt. Some of the industrialised and a few developing countries have, therefore, experimented with a few auction systems in order to improve the efficiency of and broaden participation in the Treasury bill markets; thereby increasing auction revenues.

Despite the importance of the level of public debt in South Africa, as in other developing countries, there has been less emphasis on the way and efficiency with which the government markets its securities to finance cash shortages and service the public debt. Significant improvements have been made on the management of cash balance since 1994. Surplus cash is now invested with the banks and earns sizeable amounts of interest, which should definitely offset tax increases. However, it is likely that cash management, from the marketable securities side, is not done efficiently and the costs of borrowing in South Africa may well be higher than they should be. Any savings from the efficient marketing of government securities will automatically result in an offset in the level of taxes and, conversely, any loss from inefficient marketing will be financed by the taxpayers. 
The South African Treasury bill market was not well developed during the 1980s as compared to those in developed countries. This was primarily because of government intervention, which has rendered the market grossly inefficient. According to the model employed in this study there are indications that during the era when De Kock was Governor of the SARB (the period until 1989) the Treasury bill market was operating inefficiently. However, there are signs that it may have been becoming efficient for certain sets of bills during the present decade (the Stals era). Comparison between South Africa and a few developed countries with respect to the Treasury bill market shows that the domestic market has been lagging behind those in these developed countries in terms of depth and size. There was only one exception in terms of breadth at the end of the last decade. This, possibly, explains the gross inefficiency observed in the previous decade and implies that authorities should refrain from intervening in the market.

The analyses in this study also show that a Treasury bill maturing in the last week of the month has a higher price than a bill maturing in the first week of the following month. This phenomenon holds for 11 turn-of-months differences. The remaining turnof-months average difference (May/June) is smaller than within-months average differences in absolute values, but generally average values of the turn-of-months differences are higher than the average difference of within-months pairs, in absolute values. This study, therefore, concludes that the Treasury can increase revenue from marketing its securities and reduce the costs of borrowing and financing its debt by issuing more bills maturing at the end of months. Regarding the explanation of the existence of negative differences, it is maintained that they are a result of data used and are not inconsistent with positive differences. Weekly data are used and as such the last week of the month does not necessarily include the last day of the month. The last day of the month in that case is, therefore, in the first week of the following month. This means that dates overlap in our data. It thus follows that if results are consistent those turn-ofmonths differences should be negative. It is also maintained that large average differences at the end of the months are plausible since many economic agents may well demand more bills maturing at the end of the months to pay their obligations such as salaries in accordance with the national payment system. This was confirmed by Ogden (1987) who undertook a similar study in explaining this apparent anomalous pricing behaviour in the market for Treasury bills. 
It is also demonstrated that there exists a saddle point of strategies between the Treasury and the bidders in the market. These dommant strategies iii result in a stable equilibrium where no party to the game has an incentive to change the strategy unilaterally. This Pareto optimal situation generates benefits for both the Treasury and bidders in the market, thereby improving and enhancing society's welfare. The study, therefore, argues that there is still scope for improving cash management by the Treasury. This is a major contribution of this study to the operations of the South African Treasury bill market.

In accordance with practices by the majority of countries around the world, South Africa conducts its auctions using a discriminatory method. There seems to be no obvious reason why so many countries undertake their auctions using a discriminatorypricing method. Empirical evidence regarding relative superiority between uniform-price and discriminatory auctions reveals that the former is revenue-superior. This is despite the study by Simon (1994b), which shows that the United States (US) experiment with uniform-price auctions decreased revenue from auctions and increased the Treasury's costs of borrowing. He, however, claims that the demand curve did not shift to the right enough to compensate for the loss incurred in switching from discriminatory to uniformprice auctions. It might be argued, however, that the finding by Simon (1994b) is a result of supply being greater than demand leading to less revenue, and that it does not necessarily imply revenue-inferiority of uniform-price auctions in relation to discriminatory auctions.

Most of the literature on the theory on Treasury securities auctions also states that uniform-price auction is revenue-superior to discriminatory auction, but the former is more susceptible to collusion. This implies that in the presence of collusion uniformprice auctions will yield less revenue than discriminatory auctions (Goswami et al, 1995). The fact that the majority of countries around the world use discriminatory auctions in marketing their bills is probably based on this conclusion from auction theory, that is, that discriminatory auctions are less susceptible to collusion. Some countries have experimented with uniform-price auctions and found them to be revenue-superior but they have nevertheless reverted back to discriminatory auctions. This is despite the simplicity of conducting uniform-price auctions and the evidence that they broaden bidder participation. 
The present study holds a different view regarding the design of auction techniques, and follows the reasoning that uniform-price auctions are superior to discriminatory auctions even in the presence of collusion. It also claims that discriminatory and uniform-price auctions are equally susceptible to collusion, and even if there is collusion the former are still revenue-inferior. This is in contrast with auction theory but compatible with empirical evidence, which documents revenue-superiority of uniform-price auctions. It is also consistent with the conclusion by Friedman (1960, 1991) that uniform-price auctions are revenue-superior to discriminatory auctions, but inconsistent with his conclusion that they are less susceptible to collusion. Friedman appears to have reached the right answer, but for the wrong reasons. The present study thus makes a major contribution to theoretical literature whose conclusions on auctions are in stark contrast with empirical evidence. The study, therefore, argues that the analysis presented here can be an answer to differences between the conclusions from auction theory and empirical evidence, which have long been seen as a puzzle.

Chapter 1 gives the background to the present study, notes differences between this paper and others, and also justifies the approach adopted in this paper. 


\section{Chapter 1: Background and Overview}

\section{Problem statement and purpose of study}

Cash management by the Treasury has received little or no attention at all in many countries around the world. This equally applies to the literature, which mostly side steps the issue without going into any details about the probable consequences that can arise from cash mismanagement. This is probably because of the impacts it presently has on the macroeconomy, which are perceived to be insignificant. Governments in general have, therefore, put little or no emphasis on the efficiency of cash management. This view, however, is in contrast with those of a few authors of the literature on cash management who maintain that it is very important for the operation of the economy as a whole. For example, Bloch (1964) in Van Der Knoop (1996) maintains that '... the irregular ebb and flow of government funds affects the monetary base, the supply of money, and interest and currency rates and interferes with the smooth and effective functioning of the nation's payment system. This, therefore, raises the issue of minimising the effects of the government's financial operations upon the functioning of the economy.

There are, basically, four decision variables over which the Treasury manager has control. These are the following: (a) payment schedule, (b) short-term financing, (c) marketable securities transactions, and (d) cash balance. Variables related to fixed costs like employees' salaries are beyond the control of the Treasury manager as established practice or institutional arrangements determine them, but the Treasury manager can respond to their behaviour. The Treasury manager has control over the payment schedule in terms of the size and timing. He can determine how much to pay and at which date to reduce interest costs and benefit from discounts. Short-term financing relates to borrowing that does not exceed one year. Once more in this case the financial manager determines the size and the source of such short-term financing. Marketable securities are useful for acquiring short-term cash and investing excess cash for brief periods. Governments participate in marketable securities transactions through the issue of 'Treasury bills, repo's, bankers' acceptances, certificates of deposits, state bonds, etc. These have low risk and are very flexible. In this case also the financial manager has to decide on the size and maturity dates. The yield on these securities is very sensitive to transaction costs usually expressed as the difference between bid and asked quotations by 
dealers. The net yield to the buyer is based on the asked quotation and the interest lost by the seller is equal to the bid quotation.

The decision about the optimal amount of cash balance to be held is determined by implicit costs of holding money rather than returns on investing it. Up to a certain level the implicit return on cash is very high but as more and more cash is being held it becomes increasingly expensive to keep it, as it becomes less likely that there will be shortages. The amount to be held in cash will be determined by the financial manager considering circumstances of particular situations. There is no hard rule as regards the amount of cash to be held. Any shortage from self-imposed guidelines will indicate the need for short-term financing and vice versa (Orgler, 1970).

Given the multitude of instruments that can be used for cash management by the Treasury, it is impossible to focus on all of them in determining its efficiency of cash management. However, one of the main purposes of cash management is to ensure payment of as little interest as possible on funds borrowed or to earn the maximum possible on money lent (De Zoysa, 1990). This stuay, therefore, focuses its attention on cash balance and marketable securities transactions only. For marketable securities transactions, 91-day Treasury bills are used as an object of analysis. The problem faced by the Treasury is how to market these bills in a cost-effective way in order to obtain maximum possible revenue and to keep the cash balance as low as possible in the Exchequer Account. The study, therefore, concentrates on examining operational efficiency of the Treasury bill market in South Africa and the evolution of the cash balance both with banks and the SARB over time. It, therefore, assesses implications the Treasury bill market and the cash balance have for efficiency of cash management as well as the costs of borrowing and financing the debt. It also suggests ways by which the financial operations of the government can be improved. If the marketing of these Treasury securities is not done in a cost-effective way, this tends to contradict national policies regarding the enhancement of welfare of the society. Any potential revenue lost through inefficient marketing of bills will have to be made up from increased taxation. 


\section{Scope of study}

The present study concentrates on cash management by the South African Treasury. Treasury bills as instruments for cash management are given special attention and the operational efficiency of the Treasury bill market in South Africa is examined and assessed. The cash balance of the Treasury is also put under consideration. Efficiency of cash and debt management are inseparable as they happen at the same time in the process of issuing and marketing government securities. This study, therefore, relates to both of them with emphasis on reducing the costs of borrowing. Other issues of the budget, such as capital budgeting, are beyond the scope of this study.

\section{Research methodology}

The study uses data on Treasury bills to examine the operations of the market where the Treasury markets its marketable securities. It does that by examining the efficiency in the Treasury bill market and the implications that it has for cash and debt management as well as the costs of borrowing. It also considers the cash balance and draws conclusions about the changes made regarding the treatment of cash balance for cash management. In this respect, it differs markedly from the study by Van Der Knoop (1996) in that the latter looks at cash management by putting its focus on the optimisation of cash balance in a technical and heuristic way. In testing for Treasury bill market efficiency it employs the methodology used by Fama $(1975,1976)$. This methodology differs from that employed by Godbout et al. (1999), Park (1982), and many other studies on market efficiency.

This study also examines the behaviour of prices in the market. The findings are that bills maturing at the end of the months have higher prices than those of bills maturing at the beginning of the subsequent months. The implications of this for cash management by the Treasury are therefore discussed. The study follows the methodology employed by Park and Reinganum (1986). The study by Ogden (1987) has also provided some useful information in shaping the present study's approach to the problem, although the approach followed in Ogden's study is different. The difference between the study by Park and Reinganum (1986) and the present study is that they use monthly prices of 91-day and 180-day Treasury bills issued weekly and the present study uses weekly data on discount rates of the 91-day Treasury bills. 
Lastly, the study focuses attention on auction theory, especially regarding the way effective auctions can be designed. It critically analyses the conclusions made following theoretical analyses on auctions. It suggests new ways of approaching problems such that conclusions drawn from these analyses are compatible with what is happening in the real world. The discrepancy between theory and empirical evidence from the real world has long been viewed as a puzzle in auction theory literature. In particular, the conclusions reached here are in stark contrast with the conclusions reached in a study by Bickchandani and Huang (1993).

The method employed in this study enables inferences to be made on whether there is still scope for improving cash management and lowering the costs of borrowing in South Africa. None of the other studies cited above approached the problem in the way this study does, which makes it the first of its kind. The reason why this study also focuses on marketable securities as a tool for cash management is that developing countries are more likely to intervene in the operations of markets. Developed countries usually do not influence these markets and as such the markets are generally efficient, so that no one would look at the way the government markets its securities because it is essentially being done in the best way. For instance, the study by Fama (1976) documents that the US Treasury bill market was efficient during the 1960 s and the early 1970 s. In contrast, for developing countries the marketing of securities should be cause for concern because of potential inefficiencies and government intervention.

\section{Outline of study}

Chapter 2 of this study gives a review of cash management theory and the theory of auctions. It also discusses empirical literature related to cash balance optimisation, auction theory, and efficiency of Treasury bill markets in different countries. The first section discusses cash balance theory. In the second section of the chapter the discussion of the theory of auctions encompasses both static auctions and secondary markets, because Treasury bills are not only sold in auctions (primary markets), but they are also resold in secondary markets. Conclusions reached by a number of authors regarding the superiority of different auction formats are also presented. The third section reviews empirical literature, which entails the revenue rankings of different auction formats and the efficiency of Treasury bill markets in different countries, as well as cash balance optimisation. 
The first section of Chapter 3 deals with cash management procedures of the Treasury in South Africa and the developments made in that area. The second section looks at the South African Treasury bill market. The first sub-section considers the developments made in the market from the early 1980 s up to the present time, and the second sub-section is an overview of the operational procedures and institutional set-ups of the market as well as developments up to date.

Chapter 4 outlines the data and its analysis, and documents the empirical findings from the analysis. The principal data are discount rates on 91-day Treasury bills and government deposits with banks and the SARB. As explained above, the model by Fama (1976) is used to examine the efficiency of the Treasury bill market. The study by Park and Reinganum (1986) is a guide to examining actual price behaviour in the market. The chapter also introduces a new view on how theoretical analysis on auctions can be improved. This helps to answer the apparent discrepancy between theoretical conclusions regarding auctions and empirical evidence.

Chapter 5 discusses policy implications on how cash management can be improved and how costs of borrowing can be lowered in South Africa. It also discusses the new view on how theoretical analyses on auctions can be approached and how governments should address the problem of designing effective auctions.

Chapter 6 concludes the study with the summary of the findings from the previous chapters and inferences regarding the way forward for governments and theoretical literature on auctions. 


\section{Chapter 2: Review of Theory and Evidence}

The first section of this chapter looks at the theory of cash balance. The second section discusses the economics of Treasury securities markets to give some direction regarding the theoretical underpinnings of the workings of these markets. The study provides a distinction between static auctions and auctions with secondary markets and assesses implications of these differences for the determination of prices and revenueyielding potential of the two market set-ups to the government. Most of the discussion of this issue is based on the study written by Bikhchandani and Huang (1993). The third section of the chapter reviews empirical literature related to the efficiency of Treasury bill markets. Empirical evidence regarding revenue-yielding potential of different auction formats is also considered. The effects of the issue of cash management bills on interest rates in the market, which has implications for the costs of government borrowing, are discussed in some detail. This has obvious implications for the efficiency of cash management by the central government.

\section{Cash balance}

Cash management has traditionally concerned itself with the management of cash balance of the organisation. This is a widely discussed topic in the literature, but little has been done to test the optimisation of cash balance. The idea in this case is to maintain a balance low enough to minimise opportunity costs or to maximise the implicit return of holding cash without running into cash shortages (De Zoysa 1990). Up to a certain level the return of holding cash is very high since it expresses the desire to hold precautionary balances. In this region the benefit of holding cash offsets its opportunity cost. As cash balances increase, the chance of shortage decreases and the implicit return from cash declines and approaches zero (Orgler, 1970; Baumol, 1952). There is, therefore, no clear rule on how much cash has to be held in liquid form. The level of cash to be held differs from organisation to organisation in relation to the nature of activities engaged in. For instance, some organisations are willing to hold zero cash balance and others may hold 10-percent of their working capital in cash.

Cash balance is one of the decision variables in the process of cash management. It is also important to look at the way in which cash is acquired. The question in this case is whether marketable securities are marketed in the most efficient way to meet cash shortages, that is, is the Treasury getting the maximum possible revenue it should get through the marketing of its securities? This question is of importance before one even 
looks at the cash balance optimisation itself. The following section considers the theory of marketable securities transactions and markets.

\section{Treasury's securities auction theory}

In financing their outlays governments issue Treasury bills in the money market. The way in which the Treasury bill market is structured and the way in which these bills are marketed has significant implications for the costs of government borrowing, revenue raising capabilities and the efficiency of cash management. In auctioning its Treasury bills the government can use one of a number of forms of auctions, including discriminatory and uniform-price auctions. Before discussing different forms of auctions in detail, it is important first to describe some of the general background of auction decision-making, as detailed by Bikhchandani and Huang, (1993).

\section{Static auctions}

The first assumption to consider in auction theory is the common value assumptiont Under this assumption bidders have the same value for the object even though they do not know how much it is worth. This assumption is reasonable where an object is not bought for own consumption but for resale in the secondary market. This is more appropriate for 'Treasury securities' market where the value to the bidder is a common and unknown resale price. Although resale value is unknown at the tirne of bidding each bidder is presumed to have some private and imperfect information about the value on which to base their bids. The dealers are also assumed to be unbiased so that on average their estimates are correct. In the case of 'Treasury's securities market primary dealers' private information comes from their independent forecasts and from demand requests from their clients, who are institutional buryers like insurance companies and building societies.

Secondly, the concept of common value is susceptible to the wimer's curse $e^{v}$. Assume that one indivisible object is offered for sale and that all bidders use similar rules of thumb to calculate their bids based on their estimates of the true underlying value. Although it is a common value auction with many buyers and unbiased estimates there will still be bids that are high in relation to others. As a result the higher bid will be the winning one. This is when the winner learns that other bidders actually had lower estimates of the true value. A bidder who bids too high in relation to others faces the risk of losing money despite being the winner of the auction. This has implications for 
bidding strategies by the participating bidders. In the case where the number of bidders is increasing, ceteris paribus, it is optimal to bid more conservatively. This is because the highest of more estimates is more likely to be higher than the highest of only a few estimates. Thus, having many participants in the market reinforces the winner's curse forcing bidders to shade their bids below their estimates of true underlying value by a greater amount. Nevertheless, the effect of having more bidders tends to outweigh incentives for bidding more conservatively, in that the highest bid and the selling price increase as the number of bidders increases. Another implication of the winner's curse is that as uncertainty about the value of the object decreases, the winner's curse decreases. In that case bidders tend to bid less conservatively and the selling price typically increases. This implies that in the situation where there is greater uncertainty about the true value the seller's revenue tends to be low.

In the case of discriminatory auctions the government sells its bills to the highest bidder. The bidder with the highest price bid will win the auction and pay their own price. The variant of this kind of auction procedure is a descending price auction where an auctioneer begins by naming a very high price and then lowers it continuously until some bidder stops the auction and claims the object for that price. ${ }^{1}$ The bidder chooses the price at which the object will be claimed if it has not yet been claimed and the winning bidder is the one who chooses the highest price and pays that price. Since this is the way the highest bidder wins the auction in sealed bid 'first-price auction', the sets of strategies and the mapping from strategies to outcomes are the same for both auction forms (Milgrom \& Weber, 1982; Binmore, 1992. This implies revenue equivalence between the two auction forms. When many identical units are sold, as in Treasury auctions, these two types of auctions are not equivalent, as a descending-price auction reveals more information than a discriminatory auction.

On the other hand, there is a uniform-price auction in which case the winning bidder does not pay the price they have bid but the price bid by the highest losing bidder $^{2}$. There are also variations on the way in which uniform-price auctions are conducted. As noted by Bartolini and Cottarelli (1997) a uniform-price auction can be designed such that the winner pays the price bid by the highest losing bidder set at one

${ }^{1}$ Academics call a descending price auction as Dutch auction. The financial community sometimes refers to uniform-price auction as a Dutch auction. This study does not use these names to avoid confusion. 
price unit above the highest losing bid. For instance if the highest losing bid is R20 then the winner pays R21. This latter case is exercised in Mexico and the former is exercised in the US (Umlauf, 1993). It is clear from the above that there are a number of systems which can be used for auctioning government securities, but discriminatory auctions and uniform-price auctions are the most common and are the most cited in the literature.

There are competing views in the literature regarding relative efficiency of each of these bidding systems with respect to revenue-raising potential. It is argued that if the government uses the discriminatory system of auctioning it is less likely to raise more revenue because of the existence of the winner's curse from imperfect information. For uniform-price auctions it is argued that the revenue-raising ability of the government can be improved because bidders pay the price bid by the highest losing bidder thereby reducing the risk of winners curse. This will force bidders to bid more aggressively. Milgrom (1989) and McAfee and McMillan (1987) in Simon (1994b) argue that common value auction theory with affiliated information and risk neutrality predicts that singleprice auction would lower Treasuries borrowing costs. It is also argued that this form of auction would generate more revenue to more than offset loss in revenue from awarding securities at the lowest accepted price to those who bid above that price. This is so because bidders are believed to bid more aggressively under this arrangement since at the end they pay a price less than their individual evaluations, related to other peoples' evaluations. This was the argument also raised by Friedman (1959a, 1991) in Bartolini and Cottarelli (1997), and Friedman (1959b) for the US Treasury bill market. He claimed that the simplicity of uniform-price auctions could reduce participants' costs of preparing bids, broaden their participation in auctions, and reduce incentives to funnel bids through brokers, thus narrowing the scope for brokers to collude and corner markets. A well-known case of market cornering is the Salomon squeeze of May 1991. Salomon Brothers, bidding under the brokers' names, won a 94 percent holding of the entire supply in the market (Jegadeesh, 1993 \& Jordan and Jordan, 1996).

Friedman's view has been criticised by Bikhchandani and Huang (1993) who maintain that a switch to uniform-price auction will not make non-specialists better off in the market. This is because specialists have more private information than non-specialists as regards demand conditions of securities in the market, and as a result non-specialists

${ }^{2}$ When one object is on sale, discriminatory auctions are also known as first-price auctions. Under the 
cannot make positive expected profits in the auction. They claim that one way to reduce or eliminate collusion is to make sure that there are many participants in the market, which seems to be difficult as no auction format allows for so many small bidders. Therefore, uniform-price auctions are not more likely to reduce collusion. Bikhchandani and Huang, nevertheless, agree with Friedman's view that discriminatory-pricing is to the disadvantage of non-specialists. The authors also agree that in the absence of collusion and other manipulative practices, like cornering the market, uniform-price auction yields greater expected revenue than discriminatory auction, but the latter appears to be less susceptible to collusion. This is because winning bidders pay the price they have bid and any collusive arrangement should be on fixing prices downwards. Any deviation from such prices is to the benefit of the relevant member of a cartel, making it more likely for cartels to dissolve in the case of discriminatory auction. In contrast, in uniform-price auctions, the collusive arrangement will be for one party to bid very high to guarantee winning and the remainder to bid low so that the winning bidder pays the price bid by the cartel which is lower than their private values. There is, therefore, no incentive for one party to deviate from an agreement in this case thereby guaranteeing the continued existence of collusion (Bartolini and Cottarelli, 1997).

The theory also maintains that an ascending-price auction reveals at least as much information as the uniform-price auction about the bidder's private information. In both cases the price paid by the winners is the highest losing bid; however, in an ascending price auction bidders learn more from others as they reveal their interest or lack of it in burying objects for sale. This decreases the winner's curse in the case of ascending price auctions and causes bidders to bid more aggressively. As a result average price in an ascending price auction is greater than in a uniform-price auction.

It is also argued that discriminatory-price and descending-price auctions are identical in the sense that optimal strategies and selling prices are the same in both auctions when only one unit is being auctioned. It is also pointed out that the difference comes when many identical units are being auctioned as in Treasury auctions. In this case a descending-price auction allows bidders to learn more about private information of the previous buyers thus decreasing the winner's curse and causing bidders to bid more

same conditions, uniform-price auctions are sometimes called second-price auctions. 
aggressively. Therefore, average selling price in a descending-price auction is greater than in a discriminatory auction.

On the whole, the theory of auctions predicts that, in a static one-shot situation, an ascending-price auction yields greater expected revenue to the seller than a uniformprice auction, which in turn yields greater expected revenue than a discriminatory auction. Descending-price auction is also better from the seller's point of view than discriminatory auction. Nothing can be said about the comparisons between ascendingprice and descending-price auctions as the outcomes depend on the number of objects being sold, number of bidders, and the probability distribution of bidders' estimates and common value.

\section{Secondary markets}

The discussion above focused on static auctions, but that is not sufficient in considering the Treasury securities market because of the existence of forward and resale markets. It is, therefore, appropriate to consider how different auction forms would be ranked in the secondary market. Competitive primary market bidders in the auction have more information as compared to secondary market participants. This implies that secondary market prices will be responsive to primary market bids. Bidders face costs when they increase their bids to signal to the secondary market. These costs of sending signals will differ in relation to auction formats. For uniform-price auction it is less expensive to bid aggressively because the winner pays the price bid by the highest losing bidder. For discriminatory auctions the winner pays the price bid. As a result of the nature of uniform-price auctions, bids and average winning price will be higher in uniform-price auction than in discriminatory auction.

The cost of signalling to the secondary market is the same in the case of both descending-price auction and discriminatory auction because bidders pay the prices they have bid in both auctions. But in the case of a descending-price auction information revealed by previous sales induces remaining bidders to bid more aggressively. This implies that expected revenue under descending-price auction is higher than under discriminatory auction.

In the case of an ascending-price auction more information is revealed as the price is being bid up and, therefore, bids are higher in relation to uniform-price auction 
or discriminatory auction. However, although bidders would be willing to signal to the secondary market buyers and raise the resale price, they cannot credibly reveal the auction price up to which they would have been willing to bid. This serves to decrease their auction bids compared to those in discriminatory, descending-price, and uniformprice auctions. The net impact from these offsets is indeterminate and ambiguous. It is not clear whether ascending-price auctions generate greater expected revenue than discriminatory auctions or uniform-price auctions. On the whole, descending-price auctions and uniform-price auctions yield greater expected revenue than discriminatory auctions. Unlike in static auctions, it is difficult to predict whether ascending-price auctions are better than any other auction formats (Bikhchandani and Huang, 1993).

Back and Zender (1993) in Simon (1994b) argue that the models of common value auctions referred to above by McAfee and McMillan (1987), Milgrom (1989), and Bickchandani and Huang (1989) assume that bidders bid for single units of auctioned goods, which is an inadequate framework of strategic bidding for multiple units of Treasury auctions. They demonstrate that, when the quantity dimension of Treasury auctions is modelled realistically, single-price auctions increase borrowing costs for certain classes of equilibria. It is, therefore, concluded that predictions of auction theory on whether single-price or discriminatory-price auction techniques would result in lower Treasury borrowing costs are hardly unambiguous.

As regards manipulation, a study by Chatterjea and Jarrow (1998) provides a model proving the existence of equilibrium with manipulation under both discriminatory and uniform-price auctions, even with rational participants. The model fits reasonably well in the case of the market cornering by Salomon Brothers in the US. It demonstrates that market manipulatory squeezes do not happen in the long-run equilibrium in a uniform-price auction. This, therefore, implies that uniform-price auctions are revenuesuperior to discriminatory-price auctions. The results are consistent with Friedman's view regarding uniform-price and discriminatory auctions. The analysis, however, does not go as far as incorporating potential collusion among bidders, which, they believe, could modify or possibly reverse revenue-superiority of uniform-price auctions.

This section has reviewed the theory of auctions and also presented conclusions reached by other authors using different models. The following section presents a review 
of empirical literature on cash balance optimisation, efficiency of Treasury bill markets, and revenue-superiority of different auction formats.

\section{Review of empirical literature}

Van Der Knoop (1996) has considered how the cash balance of the Dutch Treasury can be efficiently managed. In contrast to the present study, he has done that by focusing on the payment schedule of the Treasury and using heuristic algorithms. He has thus put forward a suggestion about the optimal payment dates. An optimal situation in cash management would be the one for which there is perfect synchronisation between receipts and expenditures by the central government, so that the cash balance remains zero or at a predetermined low level. But, because of uncertainty and irregularities in receipts of money from taxation as well as in outlays, the government needs to borrow from the market and also determine the payment schedule. The author uses two algorithms, namely, Great Deluge and Simulated Annealing, to determine the extent to which the government has to adjust its payment schedule to reduce the costs of borrowing. The findings indicate that the government has to settle all its payments within 26 days if its costs of borrowing are to be kept at the minimum and savings effected. It must be emphasised, however, that the algorithms used were heuristic and were not necessarily expected to yield the best possible results.

It is important at this point to look at empirical literature regarding relative superiority of different auction formats. Friedman's main argument was that a move by the government from discriminatory auction process to uniform-price auction would have an impact of increasing revenue to the government and would also dilute incentives to collude among major bidders. However, the study undertaken by Simon (1994b) on the experiment of the US government with uniform-price auctions found that 'Treasury's borrowing costs increased by seven to eight basis points over when-issued rates in relation to discriminatory auctions. This was a study undertaken for the period from 1973 through 1976. Simon argues that results imply that the demand curve did not shift out enough at single-price auctions to compensate the Treasury for the cost of foregoing price discrimination. Single-price auctions lowered Treasury revenues by $3 / 4$ percent of the face value of auctioned bonds.

In contrast to this finding by Simon (1994b), the evidence from the study by Friedman (1991) in Bartolini and Cottarelli (1997) suggested that the US Treasury 
experiment with uniform-price auctions in the 1973-1974 period may have increased revenues from auctions of long-term securities by up to 0.75 -percent. The evidence, however, is controversial because it relies largely on data from the August 1973 auction, which was under-subscribed and awarded a large portion of the securities to the US government accounts. This auction was excluded in Simon's study also because from January 1973 through May 1974 Treasury bond auctions were conducted with coupons set in advance of auctions and bids were submitted in prices. This is what caused the very poor bid for the August 1973 auction and why it was excluded from the study. The price controls in US during the time of the oil price shock were probably another factor.

Umlauf (1993) has studied the Mexican Treasury's experience with uniform-price auctions from 1990 to 1993 . A comparison of returns from these auctions with discriminatory auctions held from 1986 to 1991 reveals that the uniform-price method yielded higher revenues. Malvey et al. (1995), in Bartolini and Cottarelli (1997) found that yields from discriminatory auctions significantly exceed their contemporaneous forward yields but did not uncover the same evidence for uniform-price auctions held in 19921995. This implies that discriminatory auctions yielded lower prices than uniform-price auctions over this period. Revenue from uniform-price auctions was more volatile, but it broadened public participation in Treasury's auctions.

Other evidence, from non-Treasury auctions, also shows that uniform-price auctions are revenue-superior. For instance, Feldman and Reinhart (1995) have studied the International Monetary Fund's (IMF) auctions of gold and have found that revenues from uniform-price auctions are significantly higher than those from discriminatory auctions. This was based on a sample of 35 discriminatory auctions and 10 uniform-price auctions over a period from 1976 to 1980 . Tenorio (1993) who conducted a study on the Zambian weekly auctions of foreign exchange from 1985 to 1987 has also concluded that uniform-price auctions yield greater revenue and achieve broader investor participation than discriminatory auctions. The majority of cases, therefore, indicate that uniform-price auctions are revenue-superior to discriminatory auctions. Umlauf's findings on the Mexican Treasury bill market suggest that uniform-price auctions are also revenuesuperior even in the case of collusion. 
The puzzle in the real world is that, even given the simplicity and revenuesuperiority of uniform-price auctions, most countries around the world conduct their auctions using a discriminatory method. The survey by Bartolini and Cottarelli (1997) showed that among 42 countries included in the sample, discriminatory method was by far the most common; about 90 percent of the countries relied on it. The exceptions were Denmark and Nigeria, which were the only two countries using uniform-price auctions.

It is also important to look at the literature regarding the segmentation of markets for Treasury bills as that has implications for the effective marketing of 'Treasury bills and lowering the costs of borrowing which will in turn contribute to the efficiency of cash management. A study by Park and Reinganum (1986) documents a situation they considered empirically anomalous as regards the movement of prices of Treasury bills. They have found that those Treasury bills that mature at the end of a year have consistently lower yields than adjacent bills. They then tested several hypotheses to try to explain such behaviour involving tax effects, seasonality, and systematic mispricing of certain bills. With regard to tax effects they believec' that according to the US tax laws, the maturity differential between a bill maturing in the last week of December and one maturing in the first week of January may allow deferment of taxes on interest by as much as one year. According to their analysis the present value of taxes on the January bill is smaller than the present value of taxes on the December bill. The relative tax advantage of the January bill is also accentuated by the existence of the market for repurchase agreements (repos). If an investor borrows funds by selling a January bill through a repo and repurchases it in December, costs of borrowing are tax-deductible in the current year whereas the tax liabilities on interest are incurred the following year. As a result the expectation would be that the January bill would command a lower before-tax yield than the December bill, which was not observed. As for seasonality, the authors believed that if the spot rate of interest tends to jump at the turn of the month, the yield curve might reflect this jump. But evidence from the weekly data showed that the spot rates could not explain the exceptionally high jump in yield spreads. As regards general mispricing of the last bill in the month or the first bill in the month the evidence from data rejected such a hypothesis. 
In an attempt to explain the above anomaly Ogden (1987) has proposed a theory of month end as 'preferred habitat'. In this situation institutional arrangements of the national payment system, where transactions of many businesses and of government would be concluded at the end of the months, were believed to play an important role in the explanation of differences in yields of different pairs of bills. As a result of this arrangement those entities that have idle cash during the course of the month and obligations due at the end of the month prefer to purchase securities maturing at the end of the month rather than those maturing before or after that date. The resulting excess demand for bills maturing at the end of month causes prices to be bid up and yields to decline in relation to bills with adjacent maturities. The author used monthly and daily data to conduct empirical analysis. The first sample was monthly data where a crosssection was collected on the yields observed on the last business day of each month from January 1959 through September 1984. The second sample included the cross-section observed on each business day for the 15-month period from 1 July 1983 through 28 September 1984. The analysis was basically conducted using these data and the evidence found supported the principal hypothesis. These findings were said to have implications for Treasury debt management, short-term cash and debt management of both corporations and banks, and empirical estimation of return premiums on securities. It was pointed out that the Treasury might be able to reduce its interest costs by issuing more bills that mature at the end of the calendar months. However, the possibility was raised that interest savings may be very small, and Ogden doubts whether these lower yields would be sustained if the Treasury were to substantially increase supply of month end bills, because of the possibility of market saturation which will cause differences to evaporate.

Simon (1991) has looked at segmentation in the Treasury bill market using cash management bills as an object of analysis. He maintains that if the Treasury bill market is not segmented across adjacent maturity bills, unexpected announcements of additional supplies of particular bills should not increase interest rate differential between these bills and adjacent maturity bills. This is because market participants will arbitrage away interest rate differentials either by buying cash management bills or by selling adjacent maturity bills. Nevertheless, the findings were that announcements of cash management bills representing unexpected additional supplies of outstanding Treasury bills cause yields on these bills to rise significantly in relation to yields on adjacent maturity bills. This implies 
that cash management bills and adjacent maturity bills are not close substitutes. The study also finds that segmentation in the Treasury bill market is widespread and not limited to bills maturing across month-ends, and that segmentation is greater on the short end of the bill market.

Simon (1994a) documents further evidence on the segmentation of the Treasury bill market concentrating on relative supplies of the 12-week and 13-week Treasury bills. The study shows that differences in relative supplies of the 12-week and 13-week Treasury bills had significant and economically meaningful effects on their yield differentials from January 1985 through October 1991. Controlling for the Treasury bill yield curve the tendency of bills maturing at the end of the months to have lower yields and that of supplies augmented by cash management bills to have higher yields, and the fact that market participants do not arbitrage away the yield differentials give evidence of the fact that demand curves of individual bills are downward sloping and to the right and that segmentation is more pervasive than previously documented.

Announcements of government debt are said to have impacts on financial markets. This affects interest rates thus affecting costs of borrowing by the government. The study by Schirm, Sheehan, \& Ferri (1989) examines financial market response to Treasury debt announcements. These authors group Treasury debt announcements into four categories including regular weekly auction of 13-week and 26-week Treasury bills, the regular monthly auction of 52-week bills, mid and end of quarter auctions of notes and bonds, and irregular auctions of cash management bills. Equation 1 is used to determine the effect of unexpected announcements of new Treasury debt on interest rates.

$$
\Delta_{i}=\beta_{0}+\sum_{i=1}^{4} \beta U D_{i t}+\beta_{s} U M_{t}+\mu_{\ldots} . .(1)
$$

$\Delta i$ denotes the change in the closing rate on a Treasury security from just before to just after auction announcement, $\mathrm{UD}_{\overrightarrow{u t}}$ denotes the expected change in the $i$ th type of the Treasury debt announcement, $\mathrm{UM}_{1}$ denotes the expected M1 announcement, and the error term $\mu_{\mathrm{t}}$ is identically and independently distributed (iid). $\mathrm{UD}_{1}$ denotes 13 -week and 26-week Treasury bills, $\mathrm{UD}_{2}$ denotes 52 -week bills, $\mathrm{UD}_{3}$ denotes notes and bonds, and $\mathrm{UD}_{4}$ denotes cash management bills. For cash management bills the actual figures were 
used because there is no schedule outlining when the information about them will be released and, therefore, they are always surprises. The findings are that new information on cash management bills significantly affects daily changes in the 6-months bill rate at a 5-percent level. The coefficients on cash management bills were positive, suggesting that an announcement of a $\$ 10$ billion unexpected auction raises short-term interest rates by approximately 8 basis points. The impact of cash management bills on longer-term interest rates was generally small and insignificant, which supports the hypotheses that since cash management bills have short maturity they should only impact on short-term interest rates. This impact, however, has implications for the costs of borrowing by the Treasury.

Park (1982) in examining the efficiency of Canadian Treasury bill market used data on yields of 3-month and 6-month Treasury bills auctioned every week. To avoid serial correlation in his data he used non-overlapping data, which then necessitated the establishment of three sub-periods of interest in his analysis covering the period from May 1959 through June 1979. Equation 2 was used to conduct the analysis.

$$
R_{t+1}-R_{t}=\alpha_{0}+\alpha_{1}\left(F_{t+1}-R_{t}\right)+\varepsilon_{t+1} .(2)
$$

$R_{t+1}$ is the future spot rate of return to be determined at the end of period $t$ on a one period Treasury bill that matures at the end of period $t+1, F_{t+1}$ is the one period forward rate at period $t-1$ implicit in a two period bill and applicable to the end of $t+1$, and $R_{t}$ is the spot rate. If there is some information on the forward rate, $F_{t+1}$, about future spot rate, $R_{1+1}$, which is not captured by $R_{1}$ and if expected premium on the forward rate is constant, the estimate of $\propto_{1}$ will be close to one and that of $\propto_{0}$ gives an estimate of expected premium. 'Expected premium' was expected to be constant over time so that if the bill market were efficient Equation 3 could also be used in assessing efficiency where future spot rate is regressed on the forward rate:

$$
R_{t+1}=\alpha_{0}+\alpha_{1} F_{t+1}+\varepsilon_{t+1} .(3)
$$

In this case $\propto_{1}$ should be close to 1 and $\propto_{0}$ should be an estimate of the negative expected premium. Equation 3 is, however, inferior to Equation 2 above. 
The author used Equation 2 and found that over the period from July 1962 to March 1979 the bill market had been efficient in the sense that it correctly used information contained in past spot rates in assessing expected future spot rates and in determining forward rates. Forward rate contained information about future spot rates above and beyond that in past spot rates. Secondly, over the same period average premium implicit in the forward rate had been constant and close to zero. This zero expected premium means that the forward rate can be used as a proxy for market expectations of future spot rates. Thirdly and finally, the author documented data for the period between August 1959 and June 1962 when there was a floating bank rate and found that the data did not provide support for the constant expected premium and that it could be an indication either of inefficiency or non-constant premium. However, the concept of inefficiency is more plausible because of the intervention by the Bank of Canada in the market to deliberately resist upward or downward pressure on the bill rates.

Fama $(1975,1976)$ uses a different test of market efficiency. His study assumes that past rates of change in purchasing power are important in explaining future changes in purchasing power. With that notion in mind he assumes that in setting future spot rate in Treasury bills market participants use all information available at a point in time. This, therefore, implies that in setting future spot rate market participants will take into account the effect of inflation so as to maintain real rates of return. Autocorrelations from changes in purchasing power are, therefore, expected to be different from zero if past values are important in predicting future values.

In order for the assumption of market efficiency to make sense there has to be some assumption of market equilibrium. In this case Fama suggested that market participants wish to maintain constant real returns over time in their Treasury bills. If real returns on bills are constant it means, therefore, that any variation in spot rate should reflect variation in expected inflation. This also implies that autocorrelations from real returns have to be closer to zero.

His first regression was, therefore, to regress changes in purchasing power on one period spot rate using monthly data. If real returns were constant the coefficient on spot rate was expected to be closer to -1 and autocoorrelations of residuals were 
expected to be equal to zero. If they were not constant this coefficient would be different from -1 and residuals would likewise be different from zero. His findings were that the market was efficient from the period from January 1953 to July 1971. All his findings were consistent with assumptions employed. The results, however, changed when he included the period beyond 1971 up to 1974, which was primarily characterised by price control. This was during the time of the oil price shock and US Government resorted to price controls and rationing. For this sample period Fama finds that the market was not efficient and market participants were failing to incorporate past changes in purchasing power in predicting future changes in purchasing power. ${ }^{3}$ Coefficients of spot rate were significantly different from -1 implying that real returns were not constant over time. Therefore, neither the hypothesis of market efficiency nor that of stable real returns held for this period.

This section has dealt with empirical findings regarding optimisation of cash balance, efficiency of Treasury bill markets, and revenue-superiority of different auction formats. It is maintained that there is no hard and fast rule regarding the level of cash balance to be held by an organisation. Most empirical findings regarding revenuesuperiority of different auction formats document revenue-superiority of uniform-price auctions.

In summary, this chapter has dealt with the theory of auctions from static auctions to secondary markets or resale markets. It has considered the implications of these theories for revenue-yielding potential of government auctions. The second part has considered empirical literature regarding efficiency of the Treasury bill market. Much of the review has focused on cash management bills since they have direct implications for the costs of government borrowing and efficiency of cash management.

Chapter 3 considers cash management procedures by the South African central government and operational procedures of the Treasury bill market. This is very important in the light of the literature review and theory of auctions presented above, as it will give some directions on how South Africa can improve on its procedures.

${ }^{3}$ A detailed outline of the actual equations used by Fama is provided in Chapter 4 of this study. The identical equations are used in this study. 


\section{Chapter 3: Overview of Cash Management Procedures and the Treasury bill Market in South Africa}

The first section of this chapter looks at cash management procedures by South African central government. The nature of operations of the Treasury bill market at present are put under consideration to provide a background for the analysis in subsequent chapters. This will include, inter alia, bidding strategies used by the government in marketing its Treasury bills, frequency of issuing bills, and their maturities. Developments made up to date in the market are also considered.

\section{Cash management procedures}

Cash management procedures involve co-ordinating the volume and timing of cash receipts from taxation and other sources such as borrowing with disbursements such as repaying loans, capital expenditure, and operating expenses such as salaries. There are a number of elements of cash management systems used by Treasury departments, as outlined by Ball (1998). These are the following: cash budgeting and forecasting; collection of cash receipts; disbursement of funds; identification and investment of surplus funds; and management of foreign currency. Some of these elements have been discussed earlier in this study. This section, therefore, concerns itself with cash budgeting and forecasting as it is done in South Africa.

Accurate forecasts ensure that the government has sufficient funds to meet short-term outlays before tax receipts at the end of month. This would avoid costly borrowing from institutions such as the SARB and would also ensure that any surplus cash is properly invested with other institutions such as banks. There are different kinds of forecasts that can be undertaken to ensure that there is sufficient cash, including long-term strategic forecasts, short-term tactical forecasts prepared monthly and weekly operational forecasts.

In South Africa there are four kinds of projections undertaken by the Treasury, namely, annual projections, monthly projections, 5 months projections, and daily projections. The Treasury introduced daily projections in June 1998. The task of computing projections formerly rested mainly with the SARB, which did this on behalf of the Treasury. Changes such as introduction of daily projections happened after the Treasury took over these activities from the SARB. There are, however, a few more activities previously undertaken by other departments, such as the State Expenditure and the 
SARB, which were due to be taken over by the Treasury from August 1999. These include collating the information on monthly, 5 monthly and daily projections from individual departments, presently done by the Accountant-General (AG). The Treasury will also take over activities undertaken by the SARB at present, including determining cash-flow projection on the basis of historic cash flow trends for monetary management purposes and providing projections to the money market section, undertaken by the Economics Department. Lastly, there is a task of determining final daily flows for cash and money market management purposes, undertaken by the money market and government accounts sections of the SARB.

The exact procedure followed in cash flow management is composed of the revenue and expenditure sides. On the revenue side, the revenue estimation committee composed of representatives from the South African Revenue Service (SARS), the Budget Office (BO) and the SARB, determine and revise annual projections. On the expenditure side, government departments request budget allocations through the budgetary process to the state expenditure $(\mathrm{BO})$ that in turn determine annual projections. Annual projections from both the expenditure and the revenue side are submitted to the directorate of cash management who then compile provisional monthly cash flow statement.

Secondly, from the revenue side, the SARS provides input in March every year on overall performance to the AG, who then submits monthly projections to the directorate of cash management. From the expenditure side, government departments provide monthly projections to the $\mathrm{BO}$ and then to the $\mathrm{AG}$, who collates information resulting in monthly projections also submitted to the directorate of cash management, which leads to revision of monthly cash flow statement.

Thirdly, from the revenue side, the SARS provides input on the $15^{\text {th }}$ of each month to the AG, who collates the information into 5-monthly projections to the directorate of cash management. On the expenditure side government departments provide projections for the first two months on a weekly basis and for the last three months on a monthly basis to the AG, who then collates the information into 5-month projections to the directorate of cash management. The directorate of cash management then revises the monthly cash flow statement. 
Fourthly, on the revenue side, the input provided by the SARS on the $15^{\text {th }}$ of each month is revised when needed, resulting in daily projections on the monthly basis for two months, which are submitted to the directorate of cash management. On the expenditure side, government departments report payments exceeding R1 million that are net of receipts to the $\mathrm{AG}$, who then collates the information to daily projections that are submitted to the directorate of cash management. The directorate of cash management then compiles a daily cash flow statement. This activity started in June 1998 as mentioned above.

Finally, the Economics Department and the money market and government accounts sections of the SARB do their respective duties, as explained above. These activities result in the preparation of projections for money market meetings. The structure of these activities is presented as a chart in Appendix 1 of this study.

This section has dealt with cash management procedures by the Treasury and the developments that are taking place at present. The following section deals with the development and operation of the Treasury bill market from the early 1980 s to the present.

\section{The Treasury bill market}

\section{Developments made}

A study by Schoombee (1993) compares the development of the South African Treasury bill market with those in the US, United Kingdom, Australia and Canada for the period between 1980 and 1989. The study undertakes the comparison using size, breadth, and depth of these markets as criteria. It compares the local market with respect to level of development at the end of that decade and the development that took place over the decade. It has been found that development of the market in South Africa at the end of that decade lagged behind the average of the other sampled countries except in breadth of market. The analysis of features characterising the South African Treasury bill market led to the conclusion that monetary policy, with its emphasis on discount policy, was the major impediment to the development of local market. This caused rates of return on Treasury bills not to be market-related and to be generally low compared with those on other securities. It also negatively affected level of activity in the secondary market. The discount window that was always open, as well as shortage of cash reserves in the money 
market resulting from open market operations, public debt management and exchange market intervention, made interest rates on securities including Treasury bills tend towards rediscount rates. The study suggested that, had South Africa followed the lead of the other sampled countries and relied more on open market operations, her Treasury bill market would have been further developed and the result would have been returns on Treasury bills more related to market interest rates. Table 1 indicates results from the above-mentioned comparison.

Table 1: Comparison of Treasury bill Markets, 1980 - 1989

\begin{tabular}{|c|c|c|c|c|c|c|}
\hline & USA & $U K$ & Australia & Canada & Average & $S A$ \\
\hline \multicolumn{7}{|c|}{ Holding } \\
\hline$\%$ of $G D P$ & 8.3 & 2.2 & 2.3 & 19.1 & 8.0 & 0.7 \\
\hline \% increase & 20 & 0 & 77 & 235 & 83 & -74 \\
\hline \multicolumn{7}{|c|}{ Breadth } \\
\hline $\begin{array}{l}\text { Non-Banking } \\
\text { sector }\end{array}$ & - & 27 & 34 & 77 & 46 & 64 \\
\hline$\%$ increase & - & 590 & 2945 & 177 & 1237 & 466 \\
\hline \multicolumn{7}{|c|}{ Depth } \\
\hline Turnover rate & 18.0 & - & - & - & 18.0 & 1.1 \\
\hline \% improvement & 33 & - & - & - & 33 & -83 \\
\hline
\end{tabular}

Source: Schoombee (1993: 181)

Table 1 indicates that holdings of 'Treasury bills in South Africa as a percentage of GDP, which was 0.7 percent at the end of the decade was 11 times lower than the average holding of the other countries as a percentage of their respective GDPs. This reflects a decline in holding of 74 percent over the decade. With regard to breadth that in South Africa at the end of the decade was higher than that of all other countries but Canada. This figure was 64 for South Africa and 77 for Canada with the average of all other countries at 46 . This indicates 466 percent increase in breadth over the decade. Depth remained at 1.1 for South Africa, which was 16 times less than the figure for US (figures for other countries were not provided). This represents a decline in depth of the market by 83 percent over the decade. 
Given the shortcomings of discount policy on operations of the economy and the attendant problems, the SARB has decided to change the policy to a more flexible accommodation facility using discretionary market operations. This will, however, take time to be fully operational. The new policy emphasises repurchase transactions between the SARB and banks to regulate liquidity. Banks will be allowed to submit bids to the tender on a regular basis for central bank funds through repurchase transactions and be given the opportunity to manage their own liquidity positions more efficiently. These operations have the advantage that they can be implemented quickly. The objective is to make domestic liquidity management the most important operational tool of monetary policy. The present discount window facility will be replaced with a new marginal lending facility, but only overnight loans or loans for a number of days will be provided to banks to enable them to meet an unforeseen shortage of liquidity in the daily settlement. In a case where the discount window will have to be effected (reactivated) banks will have unrestricted access provided they furnish the SARB with accepted collateral to secure their borrowed funds, including marketable securities such as Treasury bills. The Bank rate for such purposes will generally be fixed and be at a substantial premium above the fluctuating effective interest rate on regular repurchase transactions. It will, however, still retain its purpose of serving as a signal of the monetary stance of the SARB. This new operational system is generally believed to be capable of mitigating problems experienced previously and making rates of return in the Treasury bill market more market-related (SARB, 1997a).

This sub-section has dealt with developments made in the Treasury bill market from the previous decade and recent changes made in the area of monetary policy as it directly affects the market for Treasury bills. The following sub-section deals with the nature and operational procedures of the Treasury bill market.

\section{Nature and operational procedures}

Treasury bills represent an obligation to the government to pay the investor holding such a bill a fixed sum, which is usually 91 days from date of issue. The bills are sold in the market at a competitive tender at a discount and the return obtained by the investor is equal to the difference between purchase price and face value of the security. Most of the Treasury bills issued by the South African government mature after 91 days from the day of issue. These are issued on a weekly basis on Fridays in denominations of $\mathrm{R} 10000, \mathrm{R} 20000, \mathrm{R} 50$ 000, R100 000, R500 000, R1 000 000, and R2 000000 . The 
announcement of the auction is made on the Thursday of the same week, a day before the auction takes place at 14 h00. Prior to 1958 Treasury bills were issued on application by investors provided funds were needed by the Treasury, that is, they were issued on 'tap'. From 1979 the authorities started supplementing weekly tender by the issue on a tap basis of Treasury bills with maturities of 6 and 9 months. The motive for doing that was to reduce the amount of liquidity in the banking system (Gidlow, 1981).

In addition to the 91-day Treasury bills the Treasury also issues 182-day bills. These are, however, not published for they are not considered to be official. There are also Corporation for Public Deposits (CPD) Special bills that do not earn interest as well as CPD Special bills that do earn interest. Finally, there are SARB Special tenders which are for bills with very short maturities. These are also called cash management bills as they are issued when there is an urgent need for short-term cash before taxes are paid at the end of the month and are not necessarily on issued Friday. Their maturities can be as short as 5 days.

The weekly tender is conducted by the SARB on behalf of the Treasury and tenders are invited from any person or institution. The invitation is issued through electronic news services. The invitation includes amount of bills offered, e.g. R800 million; term or maturity dates of bills for which bids are invited; closing date and time for bids; and announcement time of results of the tender. Tenderers are expected to take up and pay for their Treasury bills on any day from Monday to Wednesday following the Friday on which they were tendered for. The minimum amount for which each person can tender is R100000 and any amount beyond that should be in multiples of R10000. The method of bidding involves quoting a price and quantity of bills required, rather than discount rates. Discount rates quotations only apply to SARB special bills and must be made telephonically to the Money and Capital Market Department's dealing room in Pretoria. There is no maximum amount each bidder is expected to hold from the entire supply of bills. One bidder can effectively take up the entire supply of bills issued by the Treasury. There are approximately 20 regular bidders in the market.

The tender system used is discriminatory-pricing where participants submit closed bids in envelopes on designated forms. These forms can be submitted to any of the three branches of the SARB, namely, Johannesburg, Cape Town and Durban. 
Tenders submitted after $10 \mathrm{~h} 00$ on Friday are not accepted. Tenders from non-residents are also not accepted and any offshore investor wishing to invest in Treasury bills should appoint a domestic agent who is an authorised dealer. Bills are auctioned according to highest bidder where bidders quoting the highest prices win the auction and supply is then allocated sequentially to those who bid successively lower prices until, the entire supply is sold. The results of the auction are announced via electronic news services and successful tenderers are advised telephonically or by fax or SWIFT message. The announced results include amount allotted; amount of offers received; highest price bid; price up to which bids were fully allocated; lowest price, that is, price at which bids were partly allocated; average price; and average rate. Settlement is made on a $\mathrm{T}+3$ basis, that is, it must be done by the Wednesday following the date of auction, and all payment and collection of bills should be complete by $12 \mathrm{~h} 00$ mid-day (SARB, 1997b).

The tender system was believed to be an improvement over the previous system, where the government used to quote fixed rates, and it was thought that the new system would promote a genuine market for Treasury bills (Palmer and Dickman, 1960). However, as Wall (1973) illustrates, the tendering system came under severe criticism, as it was believed that authorities stifled development of the market through the inflexible rate pattern which tended to characterise weekly tenders. It was believed that the SARB was capable of manipulating the rate through tendering for bills itself or through the medium of National Finance Corporation (NFC), now known as the CPD, or by varying the amounts of bills offered in the tender. The NFC was changed in 1983 when the CPD was established taking over the NFC's duties. The following figure shows the relations between CPD holdings of Treasury bills and discount rates over the decade 1980-1989. 
Figure 1 : Relations of CPD Treasury bill Holding and Discount Rates (1981-1989)

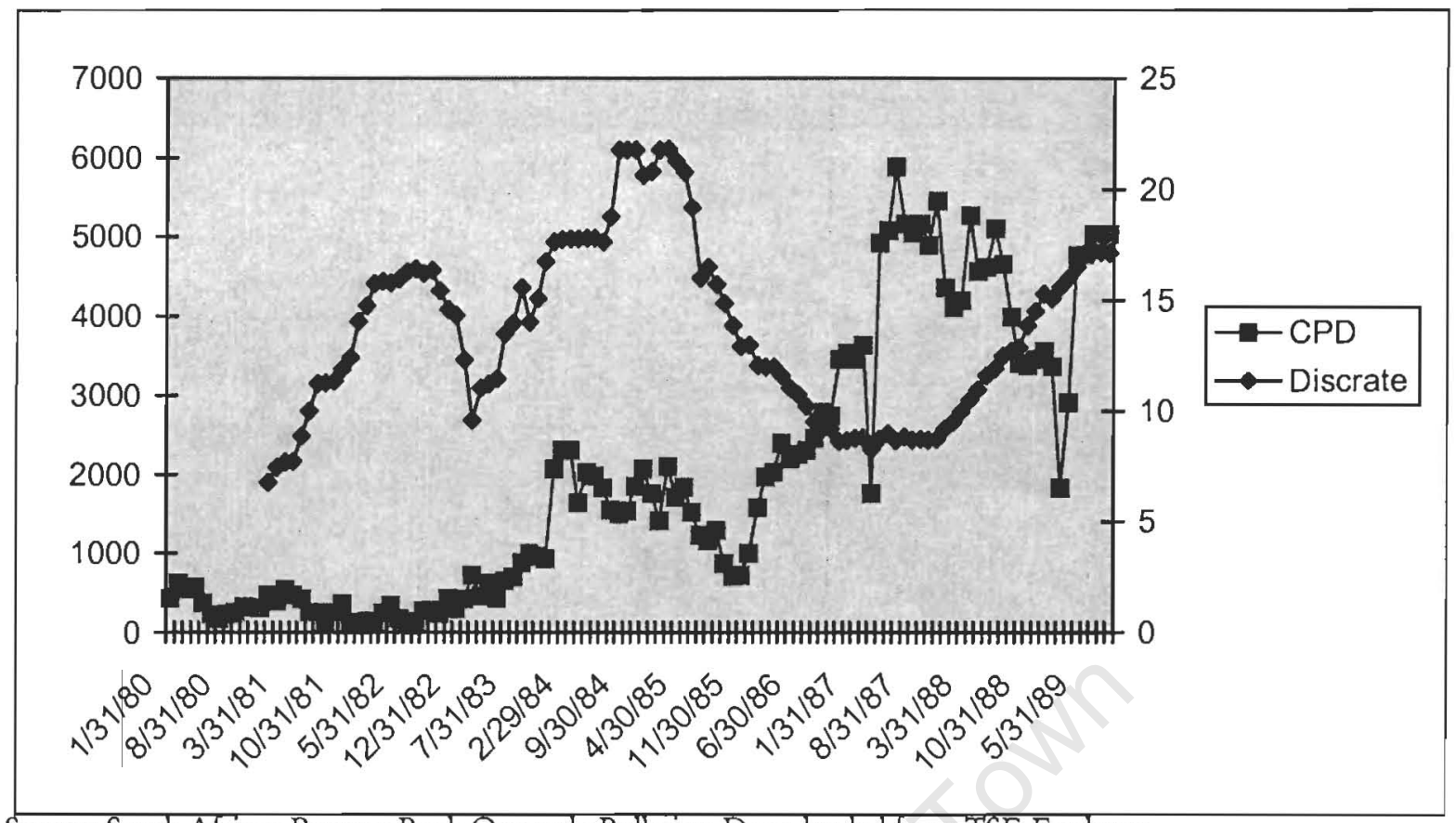

Source: South African Reserve Bank Quarterly Bulletins: Downloaded from TSE-Explorer

Figure 1 indicates that the relationship between Treasury bill rate and holdings of bills by the CPD are negatively correlated. This is what one would normally expect if the CPD were a significant participant in the market. Any increase in holding of bills should be accompanied by a decline in discount rates because the CPD has to outbid other participants in the market to win a large share of the whole market. In that way the CPD can be thought of as a significant manipulator in the market.

This behaviour of the CPD appears to have changed during the present decade. Figure 2 indicates how the CPD holding of Treasury bills has been behaving during this decade. 
Figure 2: Relations of CPD Treasury bill Holding and Discount Rates (1989-1998)

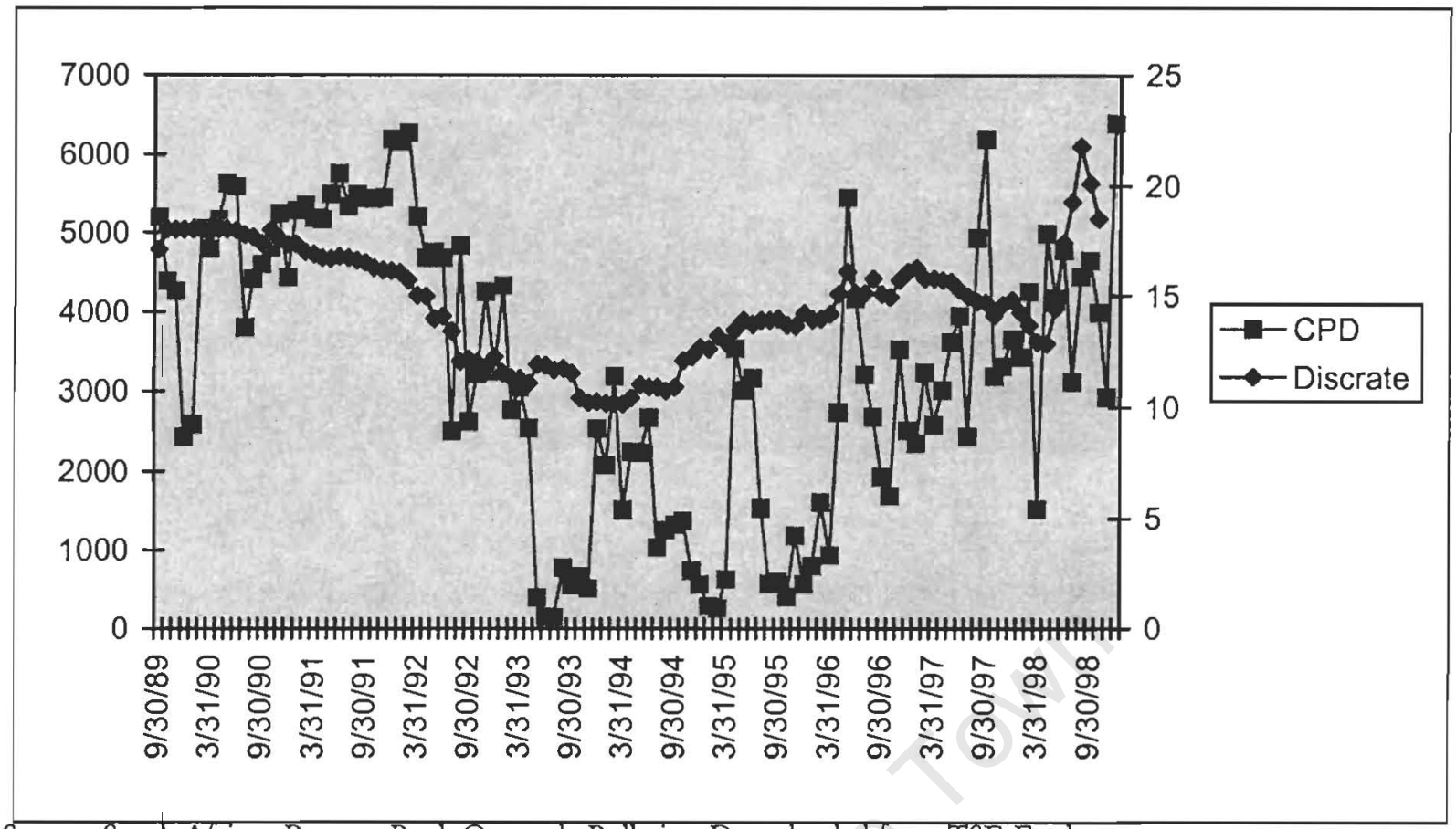

Source: South African Reserve Bank Quarterly Bulletins: Downloaded from TSE-Explorer

Figure 2 indicates that the relationship between the discount rate and holdings of Treasury bills by the CPD is positively correlated, in contrast to the previous findings. The correlation was calculated and found to be 0.61 . This may be evidence that the CPD no longer has the power it had during the previous decade and that its holdings depend on the level of discount rates. According to the relationship on the graph it is clear that when discount rate declines CPD holding of Treasury bills declines as well because the prices of bills. This possibly indicates the present inability of the CPD to manipulate market rates.

Furthermore, the SARB did not provide rediscount facilities for banks during the previous decade. Rediscounting facilities were limited to discount houses and there was an understanding that discount houses could not increase their assets when they were 'in the Bank'. 'This made it difficult for banks to acquire rediscounting facilities of the SARB through discount houses, although the latter could probably buy Treasury bills from a bank that was facing cash difficulties and resell them to the SARB. If these rediscounting facilities were available to banks they would probably provide an incentive for banks to hold more Treasury bills, although the poor yield would remain a negative factor. 
The SARB, however, had a number of reasons for not providing rediscounting facilities to banks. Firstly, it was easier to deal with only 3 discount houses than having to deal with approximately 50 banks that were existent at that time. In addition to that, since discount houses were more involved in the market for short-term assets financed by short-term liabilities, any change in the costs of dealings between them and the SARB was more likely to affect short-term money market rates instantly. In contrast, if the SARB were to provide accommodation to both discount houses and banks any change in the price of accommodation would not have the same impact on the two. This is because the banks do not have a large part of their assets and liabilities dominated by short-term assets and liabilities, as compared to discount houses.

This section has dealt with operational procedures of the South African Treasury bill market and it has also noted some important differences from other countries regarding ceilings on the share of the entire issue of bills that each bidder can hold and regarding offshore investors. It has also considered manipulatory behaviour of the CPD in the market and concluded that such conduct is not possible at present since participation has been broadened in relation to the situation in the 1980 s.

In summary, this chapter has looked at the South African situation regarding management of cash balance and conduct of the Treasury bill market. It has outlined procedures followed in South Africa in managing cash flows. Secondly, it has outlined developments made in the Treasury bill market from the early 1980 s to the present. Lastly, it has looked at the operational procedures of the Treasury bill market and has noted important differences in relation to other countries. 


\section{Chapter 4: Data, Analysis and Empirical Findings}

This chapter presents empirical findings from the analyses and considers the question of whether cash management practices in South Africa can be improved. The methodology used in this section follows that of other authors who have inquired into this topic in recent years. These include authors such as Ogden (1987). Evolution of cash balance in South Africa is first examined and improvements made are noted. Secondly, efficiency of the primary Treasury bill market in South Africa is considered. This is followed by an examination of the specific price behaviour of bills in the primary market. Finally, the question is asked as to how effective auctions can be designed.

\section{Management of cash flow}

The management of cash balance in South Africa has undergone remarkable changes. In 1994 the Treasury introduced the system in which surplus cash of the government is invested with banks. This cash management framework has been adopted to enhance working capital and efficiency, and reduce debt service cost (Department of Finance, 1999). At present there are 4 banks with which the government invests its surplus funds, namely, First National Bank (FNB), Nedbank, Amalgamated Banks of South Africa (ABSA) and Standard Bank (STD). This has resulted in the establishment of accounts with those banks, called Tax and Loan Accounts, in which the government will invest its surplus cash. These accounts are consolidated quarterly. The government in turn holds 2 accounts with the SARB, namely, the Exchequer Account and the Paymaster General Account (PMG). The Exchequer Account is perpetually credited with an amount of R500 million that serves as a buffer whenever individual departments overspend, that is, to cater for mismatches between payments and receipts. This amount does not earn interest at all. The PMG is designed to have a zero balance on a daily basis.

Individual departments submit their cash balances to the PMG on a daily basis. If they happen to spend more than they have received as income, money will be drawn from the Exchequer Account balance of R500 million to finance the shortage. Since the balance in the Exchequer Account has to be maintained in the long-run, money will, therefore, be withdrawn the following day from the Tax and Loan Accounts with the 4 banks mentioned earlier. The original R500 million will, therefore, be maintained in the Exchequer Account and a zero balance will also be maintained in the PMG. This process ensures that any injection of money into circulation is matched by an equal leakage from circulation to prevent disturbances in the operation of the economic system. The 
converse also holds. If departments spend less than they gain as tax receipts, the balance will be deposited in the Tax and Loan Accounts with the 4 banks referred to earlier. The PMG account still remains at a zero level. This pattern of cash flow management is depicted in the flow sheet shown in Figure 3.

Figure 3: Cash Flow Management Chart in South Africa

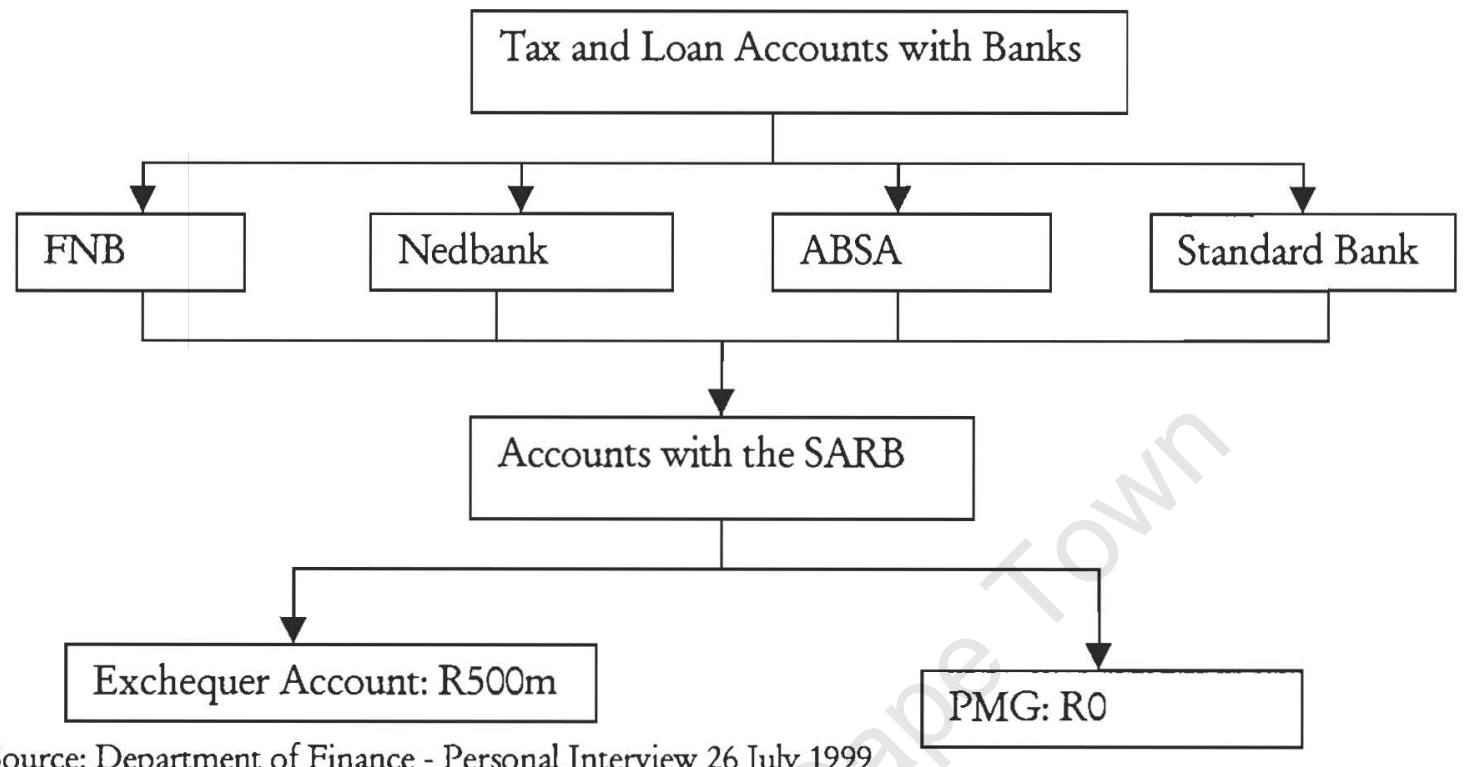

Money invested with banks in Tax and Loan accounts earns interest at an effective discount rate on Treasury bills. Efforts will be made in future to bring the amount set as a buffer in the Exchequer Account as low as possible as the system becomes more and more efficient. This will enable more money to be invested in Tax and Loan Accounts with banks. The amounts of interest earned on Tax and Loan Accounts with banks are shown in Table 2.

Table 2: Interest Earned on Tax and Loan Accounts with Banks

\begin{tabular}{|l|l|l|l|l|l|}
\hline Fiscal Year & $1994 / 95$ & $1995 / 96$ & $1996 / 97$ & $1997 / 98$ & $1998 / 99$ \\
\hline R millions & 309 & 779 & 943 & 452 & 750 \\
\hline
\end{tabular}

Source: Department of Finance (1999)

Table 2 indicates that interest received from Tax and Loan Accounts is substantial and generally exceeds the amount kept with the SARB as a buffer for overspending by agencies. This is an obvious improvement from the system followed before 1994. 
On the other hand, from the beginning of April 1998, transfers to provinces are now spread over a 5-week period, which has resulted in a more even distribution of daily cash requirements. This is in contrast with the system employed previously where payments to provinces were made on the first working day of each week.

The changes discussed above have necessitated a decline in government deposits with the SARB and an increase in deposits with banks. This should have a positive effect on efficiency of cash management and it should also mitigate the need to finance expenditure through taxes.

Figure 4 below indicates government deposits in the PMG Account with the SARB over the period 1980-1998.

Figure 4: Government Deposits in PMG Account with the SARB

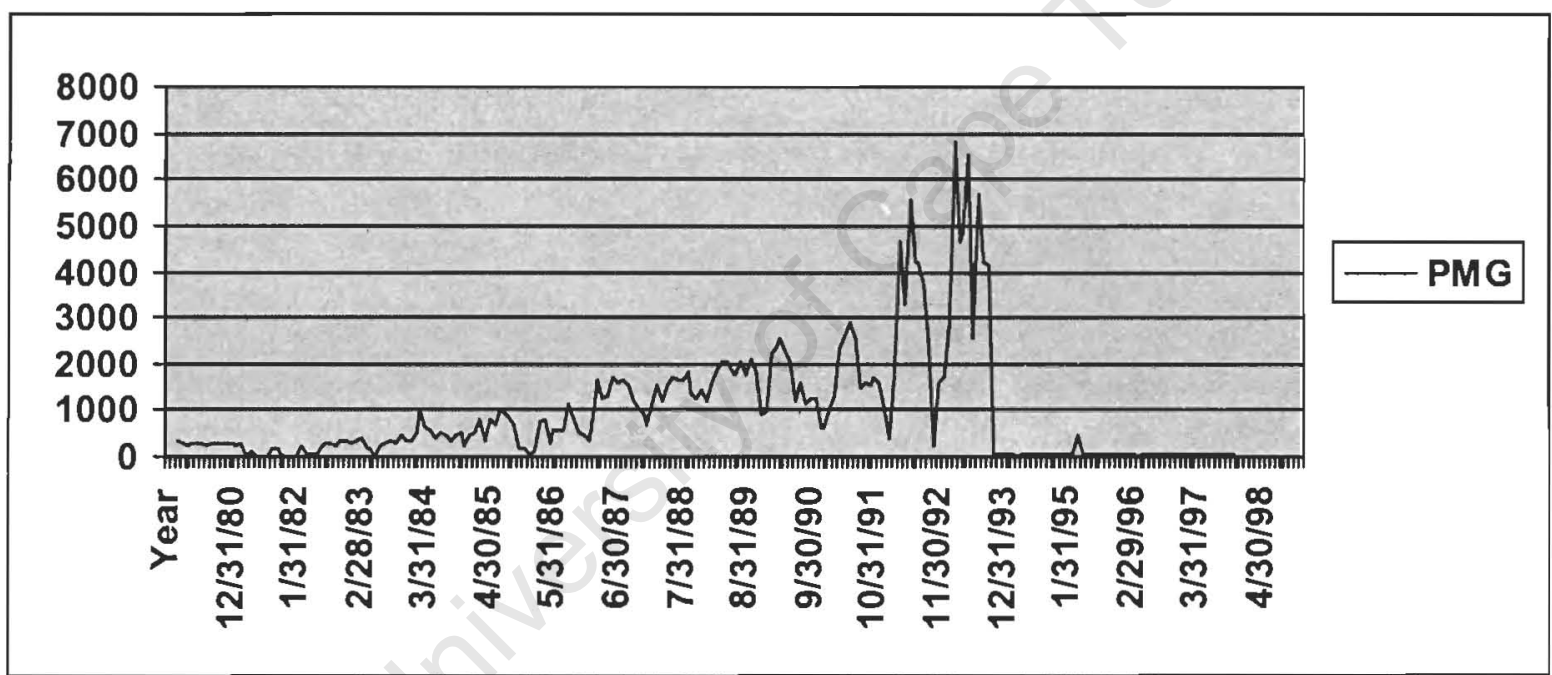

Source: SARB Quarterly Bulletins (Various Issues) - Downloaded from TSE-Explorer

Figure 4 indicates that the PMG balance in the SARB is staying at or close to zero in response to the new cash management procedures. This is evident from 1994 onwards. The balance reached its highest level during the early 1990s but was occasionally close to zero during the early 1980 s.

Figure 5 indicates government deposits with the SARB from the early 1980 s to the present. 
Figure 5: Government Deposits with the Reserve Bank

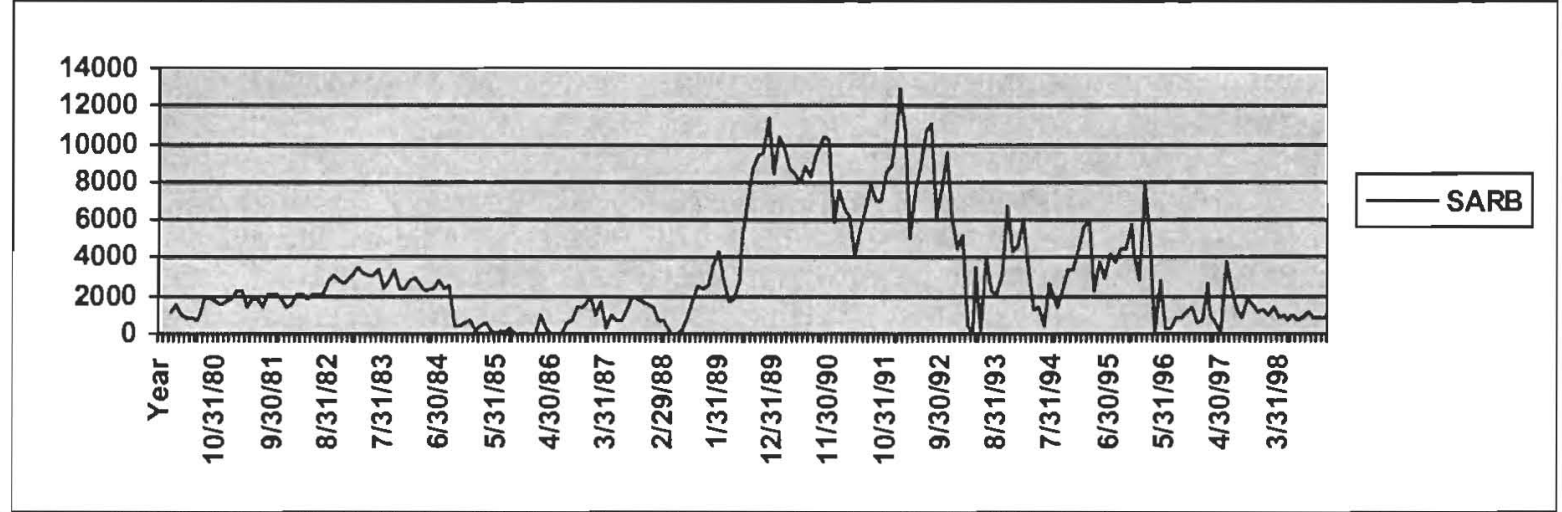

Source: SARB Quarterly Bulletins (Various Issues) - Downloaded from TSE-Explorer

Figure 5 indicates that government deposits with the SARB have been declining since 1994 when the new cash management practices were introduced.

Figure 6 indicates government deposits with the banks.

Figure 6: Government Deposits with Banks

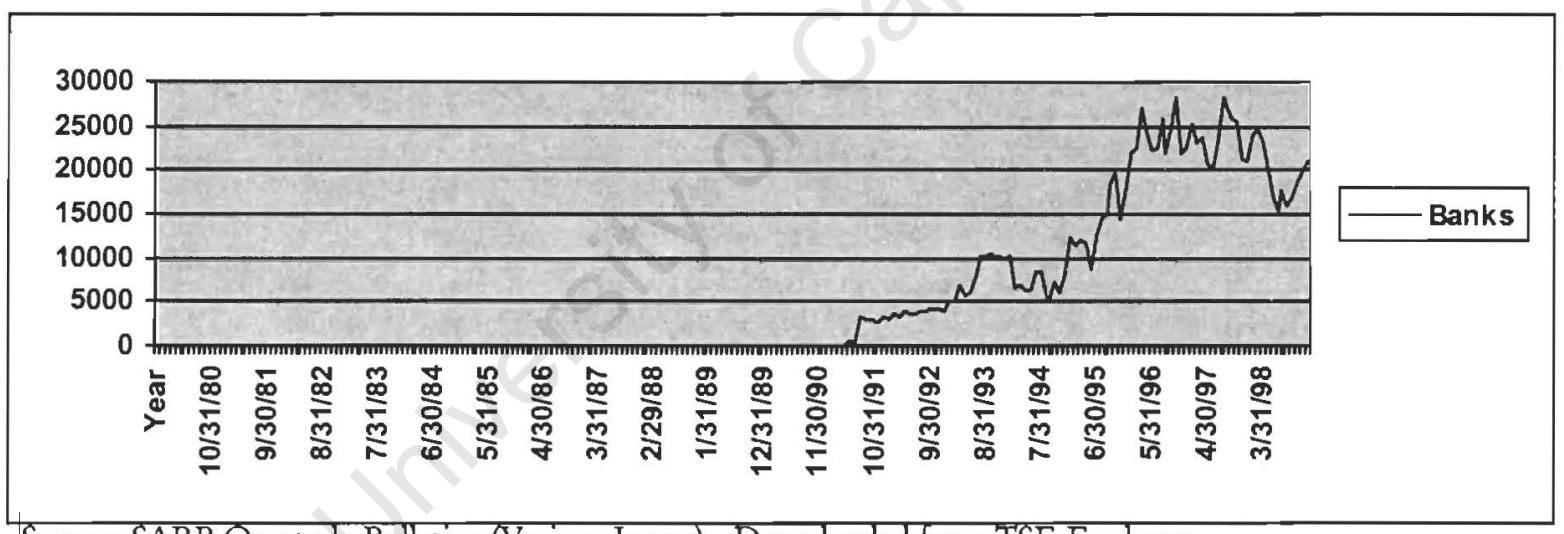

Source: SARB Quarterly Bulletins (Various Issues) - Downloaded from TSE-Explorer

Figure 6 indicates that government deposits with banks have been increasing from the early 1990s, when new practices were adopted for cash management.

The operation of projected cash flow requirements will now be illustrated. A close examination of the daily cash flow estimates for May 1998 indicates that there is more likely to be shortages of cash towards the end of the months. This necessitates issuance of bills with very short maturity to finance temporary cash shortages. Overall monthly cash flows also necessitate the need to issue other kinds of bills with longer maturities to meet gross borrowing requirements (GBR). 
Figure 7 shows cash flow requirements for 1998/99 in millions of Rands on a monthly basis.

Figure 7: Cash Flow Requirements for 1998/99 in Rm

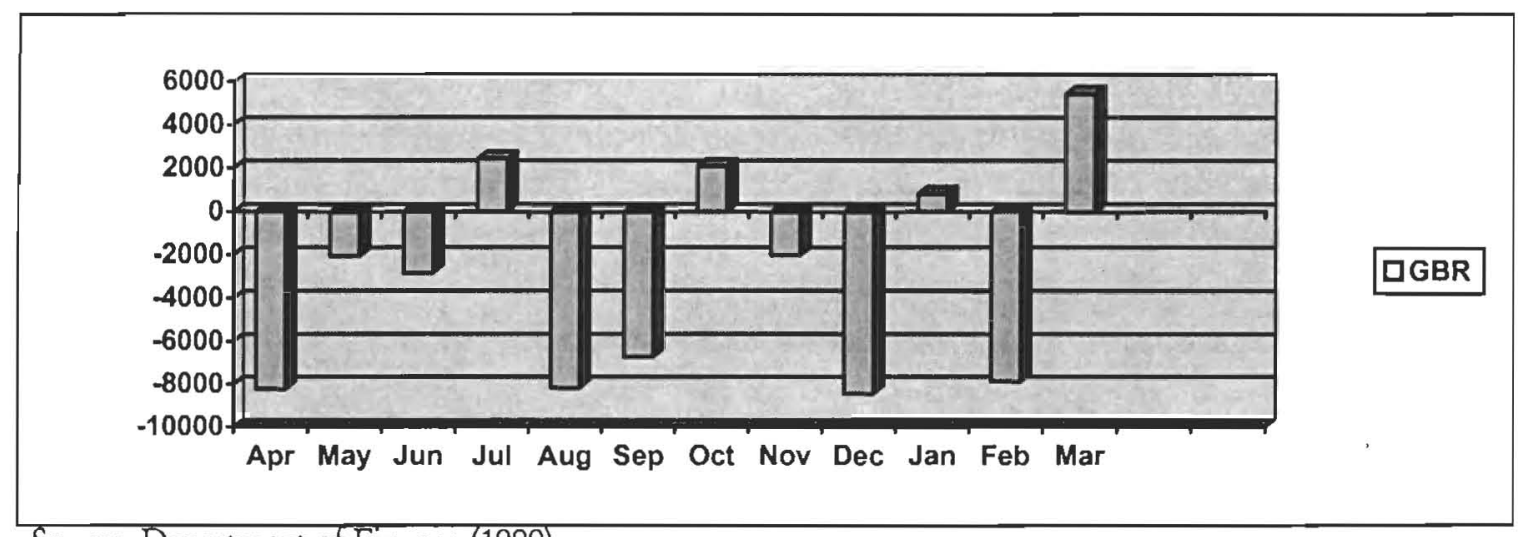

Source: Department of Finance (1999)

Figure 7 shows that high seasonal expenditure during April 1998 resulted in a deficit for that month. Interest payments of about R9.0 billion during each of the months of August and February and repayments of loans of R5.6 billion and R9.4 billion during September and December, respectively, resulted in high cash shortages for these months. These factors account for high cash flow peaks during the 1998/99 financial year. Similar factors also necessitate high cash requirement projections for the 1999/00 financial year in April, August and February. This also applies to the repayment of a domestic loan of R7.5 billion in November and a foreign loan of about R5 billion in December.

In response to these cash shortages Treasury bills were issued to finance them and amounts varied in response to high payment requirements of loans and seasonal expenditure. Figure 8 shows the issue of Treasury bills over the 1998/99 fiscal year. 
Figure 8: Issuance of Bills to Meet Cash Shortages for 1998/99 in Rm

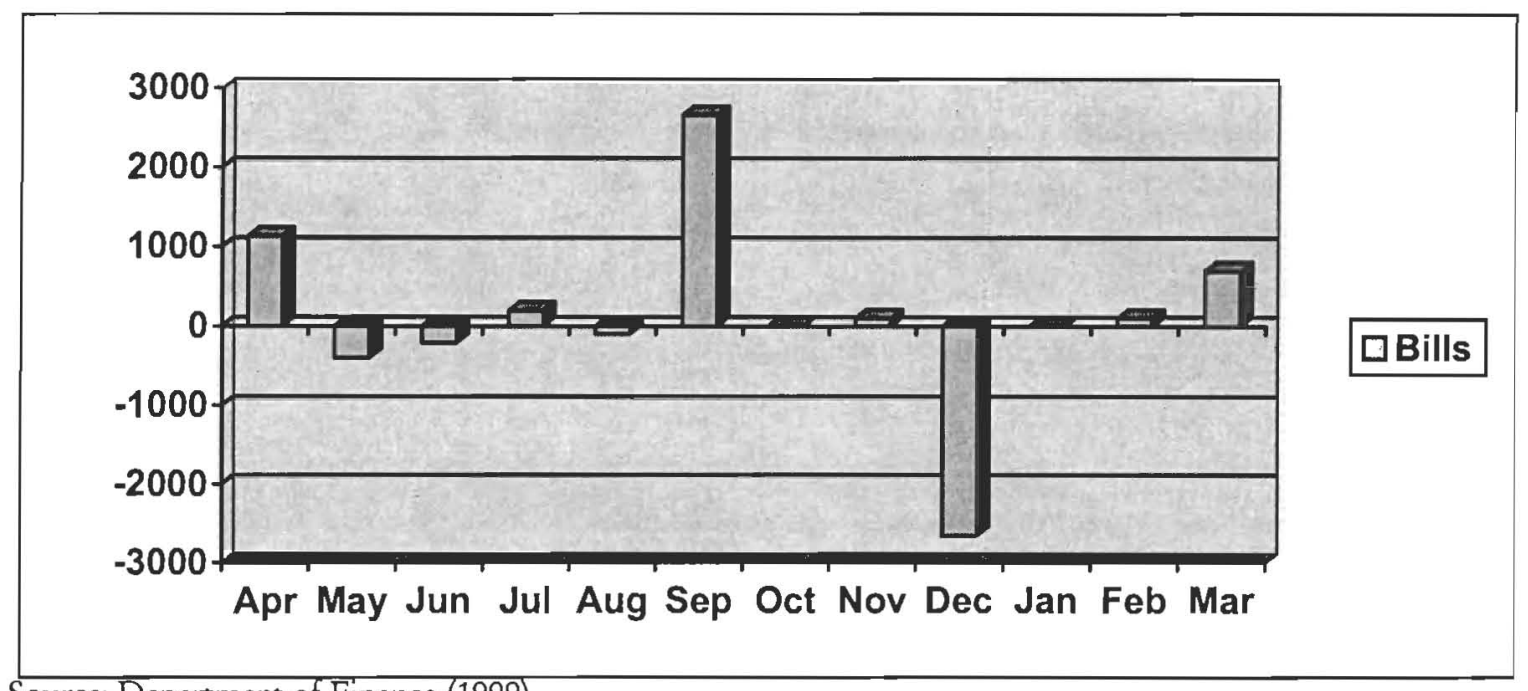

Source: Department of Finance (1999)

Figure 8 shows that the September issuance was exceptionally high in relation to other months. This is due to the repayment of a loan during that month and the fact that it is a month during which there are provisional tax payments. The amount, however, is redeemed in part in October and the remainder in December. The Treasury issued only one special bill to the value of R900 million, that is, one with short maturity, issued in December and redeemed in January.

At a time when there is a desire to reduce deficits to acceptable levels it is appropriate to let the Treasury handle its cash management task in the best possible way in order to maximise its interest earning assets. It is possible that amounts involved as interest earned are not high in relation to total government revenue, but still they could ease tax burden to some extent. The public should also benefit from improved cash management by the Treasury. Tax rates needed to meet any level of expenditure should decline to a certain extent (Wilson, 1975, 1977).

This section has focused its attention on cash balance as a decision variable in cash management. It is noted that there are improvements in the nature of the activities the Treasury undertakes in performing its cash management task and that this should result in overall benefits to society, however small these benefits are. The following section analyses marketable securities transactions and their market. 


\section{Marketable securities transactions}

\section{Primary market efficiency}

This section follows directly from the work by Fama (1976). In conducting the analysis of market efficiency it is assumed that past inflation rates are important in predicting future movements in inflation rates, namely, market participants use information on past inflation rates to forecast future inflation rates. In this sense it follows that in setting prices of bills in the market they will take into account effects of inflation on returns of these bills when they mature. This is because nominal returns may well be positive, yet real returns are negative. It is hypothesised that market participants maintain constant real returns over time, ie, real returns follow a mantingale process. ${ }^{\text {vi }}$ The martingale hypothesis has long been considered as a necessary condition for efficiency of an asset market, one in which the information contained in past prices is instantly, fully, and perpetually reflected in an asset's current price (Samuelson, 1965, 1972, 1973 \& Roberts, 1967) in Campbell, et al (1997). This assumption follows from the importance of assuming some form of market equilibrium when one is studying the behaviour of markets. This is what Fama also suggested. If this assumption holds it turns out to be even more important for cash management by the Treasury because it will ensure the stability of real value of revenue from marketing Treasury bills. This is the most important requirement for efficient cash management.

Data used are discount rates from various issues of the SARB Quarterly Bulletins downloaded from TSE-Explorer. Since auctions on 91-day Treasury bills are undertaken every week, data are on a weekly basis. However, the time to maturity of these bills is 91 days, which is 3 months on average. Using data as they are is problematic because they are overlapping over periods. They are, therefore, transformed into monthly data. The process followed in transforming them was to take the observation of the first week of the first month and that of the last week of the third month from each 3-months interval. The data are, therefore, monthly in 3-months intervals and there are two sets of data, one from the beginning of the period and the other from the end of the period. The data used are, therefore, non-overlapping and are of necessity free of unnecessary serial correlation as the analysis rests on residuals. Unnecessary serial correlation on the results would, therefore, result in inefficient estimates. To see how results are altered over time data are also segmented into two sub-periods, namely, the De Kock and Stals periods, and results are replicated for them. 
The assumption of maintenance of real value of returns makes sense only if information about past rates of inflation is important for making decisions about the future. For empirical analysis it means, therefore, that autocorrelations from purchasing power series should be high for this assumption to be true. Since expected inflation is also embedded in determining nominal returns it also means that nominal returns do not have to explain real returns. This also holds if the assumption of constancy of real returns holds. Therefore, the study of autocorrelations of real returns is a joint study of market efficiency and validity or usefulness of the model as regards the assumption of constant real returns. All the above explanations are summarised in the following paragraph by equations used to estimate results.

The measure of inflation was proxied by the consumer price index (CPI) as published in the SARB Quarterly Bulletins and downloaded from 'TSE-Explorer'. To compute the index of purchasing power $(\Pi)$ the reciprocal of CPI in 1995 prices is used computed as follows:

$$
\Pi=\frac{1}{C P I}
$$

Nominal returns were computed in three monthly rates as follows:

$$
i=\frac{\left(v_{t}^{*} v_{t-1}\right)}{v_{t-1}} \ldots(5)
$$

$v_{t}$ is price of the bill at the end of period (date of maturity) and $v_{t-1}$ is price of the bill at the beginning of period. In order to obtain a real return one has to multiply price of the bill by purchasing power index. The relation between inflation and price of the bill is that during times of inflation, purchasing power of the bill declines and during deflation, unusual times, purchasing power of price of the bill rises. There is, therefore, a negative relationship between the two. Real returns were, therefore, also computed in 3months rates as follows:

$$
r=\left(\frac{\prod_{t} * v_{t}-v_{t-1} * \Pi_{t-1}}{v_{t-1} * \prod_{t-1}}\right) \ldots(6)
$$


$\Pi_{t}$ is purchasing power of South African Rand in terms of goods included in calculation of CPI. Change in purchasing power over time is calculated as follows:

$$
\Delta_{t}=\frac{\left(\pi_{t}-\pi_{1-1}\right)}{\pi_{t-1}} \ldots(7)
$$

Therefore, the first regression run is as follows:

$$
\Delta=\alpha+\beta R_{t}+\varepsilon_{1} .(8)
$$

$R_{T}$ in this case denotes nominal return. If real returns are constant over time the coefficient $\beta_{\mathrm{t}}$ is expected to be -1 because $\beta_{\mathrm{t}}=\gamma-1.0$ where $\gamma$ is a measure of variation of the real returns over time. If variations of real returns are zero, meaning that real returns are constant then $\gamma=0$ and $\beta_{\mathrm{t}}=-1.0$, reflecting the market assessment of the expected rate of change in purchasing power. If the market is such that it is efficient, in the sense that it utilises all information contained in past rates of inflation, and real returns are constant, residuals from (8) should be closer to zero. Thus, in this special case where $\gamma=0$ the relevant equation is as follows:

$$
r_{1}=a_{0}+\lambda R_{t}+e_{1 \ldots}(9)
$$

If the real returns are not constant over time then $\lambda$ from (9) will be non-zero. On the other hand, if the market is not utilising all information available at a point in time when it sets $R_{t}$ then there should be other variables, which should also explain variation in change of purchasing power over time. To investigate that, it is important to come up with an alternative hypothesis saying that the market does not utilise all available market information in setting future spot rate. And if this is the case it will, therefore, mean that the market is inefficient. One past value of purchasing power is chosen to investigate this phenomenon. The relevant equation is as follows:

$$
\Delta t=c_{0}+c_{1} R_{t}+c_{2} \Delta_{t-1}+e_{t} . .(10)
$$

If the coefficient of the lagged value of purchasing power is non-zero, it means that the market disregards some of the important information in $t-1$ when setting $R_{t}$, which is nevertheless public information and freely available. The residual 
autocorrelations from Equation 10 should be zero if the market is efficient. The variable of past value of purchasing power in Equation 10 is chosen arbitrarily; one could have chosen any other like money supply (M3 preferably). Equations 8 and 10 can, therefore, be used in testing the assumption of market efficiency and Equation 9 can be used directly to test the assumption of constant real returns over time.

Before conducting the analysis it is important to make a few important comments about the economic situation in South Africa from the early 1980 s to the present. The sample used is composed mainly of two time periods during which economic policies are different. The first is the period until 1989 when De Kock was Governor of the SARB and the second is the post-1989 period when Stals was Governor. In the former period there was a high degree of interest rate controls while in the latter period there was lessening of these controls until now. The point has been reached when the Bank rate is no longer a primary target for monetary policy. For the first sub-period real interest rates were usually negative because of controls. For the second sub-period interest rates were positive most of the time. There is also a potential difference between pre-election period and post-election period for the second subsample. It is also important to distinguish between these periods, but the problem is that there are not enough observations over that period. The results were computed and were the same on average except for the fact that the post-election period has higher real returns. They are thus not shown in this paper, to conserve space. Figure 9 shows a plot of real returns used in this paper.

Figure 9: Real Returns on Treasury bills

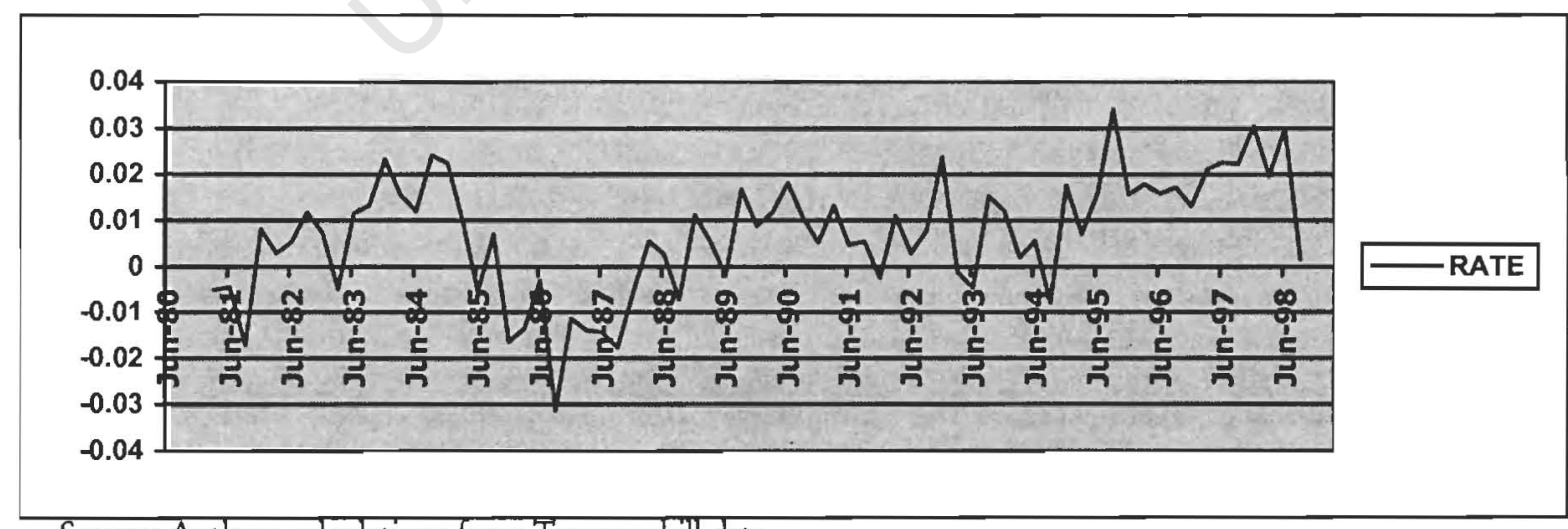

Source: Authors calculations from Treasury bill data

Figure 9 indicates that there were times when real returns were negative and were unstable during the pre-1989 period. It also shows that for the post-1989 period real 
returns are more stable than they were in the pre-1989 period. They also appear to be higher for the post-1994 period, which should reflect risk from openness of the economy in transition. The assumption of constant real returns, therefore, makes sense only in the post-1989 period.

The following are empirical findings from regression of the above equations for all sub-periods. Table 3 shows autocorrelations of changes in purchasing power.

Table 3 : Autocorrelations of Change in Purchasing Power $\left(\Delta_{\mathrm{r}}\right)$

\begin{tabular}{|l|l|l|l|l|l|l|l|l|}
\hline Period & & $\rho_{1}$ & $\rho_{2}$ & $\rho_{3}$ & $\rho_{4}$ & $\Delta$ mean & $\mathrm{S}(\Delta)$ & $\mathrm{T}$ \\
\hline $80 / 2-$ & Begin & 0.017 & 0.102 & 0.365 & 0.091 & -0.033 & 0.008 & 35 \\
\cline { 2 - 9 } $89 / 2$ & End & 0.112 & 0.098 & 0.439 & -0.002 & -0.033 & 0.008 & 35 \\
\hline \multirow{8}{*}{$\begin{array}{l}89 / 3- \\
98 / 4\end{array}$} & Begin & 0.495 & 0.290 & 0.345 & 0.132 & -0.024 & 0.009 & 38 \\
\cline { 2 - 9 } & End & 0.218 & 0.236 & 0.236 & 0.177 & -0.024 & 0.010 & 38 \\
\hline
\end{tabular}

Source: Author's calculations from Treasury bill data. $\rho$ indicates lags of autocorrelations, , $\Delta$ mean indicates the mean of change in purchasing power, $s(\Delta)$ indicates its standard deviation, and $T$ is the number of observations.

Table 3 indicates that autocorrelations of changes in purchasing power are different from zero for the third lag of the first sub-period for data from both the beginning and the end of the period. From the second sub-period, the first and the third autocorrelations are different from zero whereas the remainder are not. For those autocorrelations different from zero it means that past changes in purchasing power are important in predicting its future changes consistent with the assumptions made. Table 4 shows autocorrelations of real returns

Table 4: Autocorrelations of Real Returns

\begin{tabular}{|l|l|l|l|l|l|l|l|l|}
\hline Period & & $\rho_{1}$ & $\rho_{2}$ & $\rho_{3}$ & $\rho_{4}$ & $r$-mean & $\mathrm{S}(r)$ & $\mathrm{T}$ \\
\hline $80 / 2-$ & Begin & 0.502 & 0.506 & 0.422 & 0.249 & 0.0001 & 0.013 & 34 \\
\cline { 2 - 9 } $89 / 2$ & End & 0.571 & 0.506 & 0.484 & 0.287 & 0.0006 & 0.013 & 34 \\
\hline $\begin{array}{l}89 / 3- \\
98 / 4\end{array}$ & Begin & 0.397 & 0.245 & 0.424 & 0.084 & 0.012 & 0.009 & 38 \\
\cline { 2 - 9 } & End & 0.256 & 0.272 & 0.303 & 0.108 & 0.012 & 0.009 & 38 \\
\hline
\end{tabular}

Source: Author's calculations from Treasury bill data. $\rho$ indicates lags of autocorrelations, $r$-mean indicates the mean of real returns, $s(r)$ indicates its standard deviation, and $T$ is the number of observations. 
The table above also indicates that autocorrelations of real returns are significantly different from zero for all but data from the end of the second sub-period. For end of the second sub-period it means, therefore, that real returns are constant over time consistent with assumptions made. This, however, contradicts results found on the previous table where changes in purchasing power from the end of the second subperiod were characterised by low autocorrelations. It means that during times when past changes in purchasing power are of irrelevance then the market tends to be more stable than before. ${ }^{4}$ Table 5 shows autocorrelations of changes in nominal returns.

Table 5: Autocorrelations of Change in Nominal Returns

\begin{tabular}{|l|l|l|l|l|l|l|}
\hline Period & & $\rho_{1}$ & $\rho_{2}$ & $\rho_{3}$ & $\rho_{4}$ & $\mathrm{~T}$ \\
\hline $80 / 2-$ & Begin & 0.384 & 0.352 & -0.025 & -0.016 & 33 \\
\cline { 2 - 7 } $89 / 2$ & End & 0.228 & 0.349 & -0.031 & -0.069 & 33 \\
\hline \multirow{2}{*}{$\begin{array}{l}89 / 3- \\
98 / 4\end{array}$} & Begin & 0.060 & 0.088 & 0.001 & -0.035 & 37 \\
\cline { 2 - 7 } & End & 0.147 & 0.092 & 0.000 & -0.014 & 37 \\
\hline
\end{tabular}

Source: Author's calculations from Treasury bill data. $\rho$ indicates lags of autocorrelations and $T$ is the number of observations.

The results on Table 5 show that for the first sub-sample the first two autocorrelations are different from zero for the data from the beginning of the period and only the second autocorrelation for data from end of the period. Autocorrelations for the second sub-sample are all not different from zero meaning that nominal returns fail to predict changes in purchasing power. This contradicts the hypothesis about behaviour of nominal returns. Table 6 shows regression of changes in purchasing power on nominal returns.

${ }^{4}$ The possible causes of this will be discussed later. 
Table 6: Regression of Change in Purchasing Power on Nominal Returns

\begin{tabular}{|c|c|c|c|c|c|c|c|c|}
\hline Period & & $a_{0}$ & $a_{2}$ & $\mathrm{R}^{2}$ & $\rho_{1}(e)$ & $\rho_{2}(e)$ & $\rho_{3}(e)$ & $\mathrm{T}$ \\
\hline \multirow{2}{*}{$\begin{array}{l}\stackrel{N}{\alpha} \\
\infty \\
\dot{1} \\
\stackrel{े}{\infty}\end{array}$} & Begin & $\begin{array}{l}-0.033 \\
(-6.63)\end{array}$ & $\begin{array}{l}0.002 \\
(0.01)\end{array}$ & 0.00 & 0.030 & 0.170 & 0.351 & 34 \\
\hline & End & $\begin{array}{l}-0.033 \\
(-6.61)\end{array}$ & $\begin{array}{l}0.002 \\
(0.02)\end{array}$ & 0.00 & 0.157 & 0.120 & 0.406 & 34 \\
\hline \multirow{2}{*}{$\begin{array}{l}+ \\
\stackrel{+}{\alpha} \\
\dot{1} \\
\stackrel{2}{\infty}\end{array}$} & Begin & $\begin{array}{l}0.0016 \\
(0.19)\end{array}$ & $\begin{array}{l}-0.694 \\
(-3.31)\end{array}$ & 0.23 & 0.383 & 0.215 & 0.380 & 38 \\
\hline & End & $\begin{array}{l}0.0026 \\
(0.30)\end{array}$ & $\begin{array}{l}-0.718 \\
(-3.10)\end{array}$ & 0.21 & 0.229 & 0.221 & 0.252 & 37 \\
\hline
\end{tabular}

Source: Author's calculations from Treasury bill data. $a_{0}$ and $a_{1}$ indicate coefficients of the model, $\mathrm{R}^{2}$ is coefficient of determination, $\rho$ 's are autocorrelations of residuals from 1 to 3 , and $T$ is the number of observations. T-statistics are in parenthesis.

Table 6 shows the first regression, which was run estimating Equation 8. The hypothesis says that the constant is a measure of expected value of real returns and coefficient on nominal returns indicates the proportion of variation in nominal returns that explains variation in changes in purchasing power. If the market is efficient, coefficient on nominal returns must be equal to -1.0 and residual autocorrelations should be closer to zero. A close examination of the table shows that none of the serie has residuals closer to zero except that at the end of the second sub-period. This series is highlighted in yellow and is compatible with the hypothesis of market efficiency. The Wald-test was computed and confirmed the hypothesis that the coefficient on nominal returns is equal to -1 at 5 -percent level of significance. Table 7 shows the regression of changes in purchasing power on nominal returns and lagged changes purchasing power. 
Table 7: Regression of Change in Purchasing Power on Nominal Returns and Lagged Purchasing Power

\begin{tabular}{|c|c|c|c|c|c|c|c|c|c|}
\hline \multicolumn{2}{|c|}{ Period } & $a_{0}$ & $a_{1}$ & $a_{2}$ & $\mathrm{R}^{2}$ & $\rho_{1}(e)$ & $\rho_{2}(e)$ & $\rho_{3}(e)$ & $\mathrm{T}$ \\
\hline \multirow{2}{*}{ 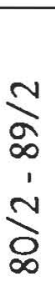 } & Begin & $\begin{array}{l}-0.032 \\
(-3.7)\end{array}$ & $\begin{array}{l}-0.0007 \\
(-0.004)\end{array}$ & $\begin{array}{l}0.0175 \\
(0.098)\end{array}$ & 0.00 & 0.010 & 0.164 & 0.347 & 34 \\
\hline & End & $\begin{array}{l}-0.028 \\
(-3.18)\end{array}$ & $\begin{array}{l}-0.020 \\
(-0.14)\end{array}$ & $\begin{array}{l}0.123 \\
(0.66)\end{array}$ & 0.014 & 0.031 & 0.052 & 0.405 & 34 \\
\hline \multirow{2}{*}{$\begin{array}{l}+ \\
\stackrel{े}{\infty} \\
\dot{\infty} \\
\stackrel{2}{\alpha}\end{array}$} & Begin & $\begin{array}{l}0.0020 \\
(0.27)\end{array}$ & $\begin{array}{l}-0.446 \\
(-2.08)\end{array}$ & $\begin{array}{l}0.397 \\
(2.66)\end{array}$ & 0.36 & -0.035 & -0.097 & 0.335 & 38 \\
\hline & End & $\begin{array}{l}0.0041 \\
(0.46)\end{array}$ & $\begin{array}{l}-0.612 \\
(-2.53)\end{array}$ & $\begin{array}{l}0.222 \\
(1.39)\end{array}$ & 0.25 & -0.009 & 0.099 & 0.188 & 38 \\
\hline
\end{tabular}

Source: Author's calculations from Treasury bill data $a_{0}, a_{1}$, and $a_{2}$ indicate coefficients of the equation, $R^{2}$ is coefficient of determination, $\rho$ 's are autocorrelations of residuals from 1 to 3 , and $T$ is the number of observations. T-statistics are in parenthesis.

Table 7 shows results from Equation 10 where the lagged value of change in purchasing power is also included. The hypothesis here is that if the market takes into account all information available in the market at the end of the pervious period $(t-1)$, then any lagged value of the dependent variable should not explain variations in the dependent variable. This implies that all information relevant in making decisions should be incorporated in setting nominal rate of return and coefficient on nominal returns should still be equal to -1.0 and that of the lagged value should be equal to zero.

Residuals as well have to be insignificantly different from zero. A close examination of the results indicates that the requirement only holds for the end of the second sub-period as before and residuals are very close to zero as implied by the assumptions. Table 8 shows regression of real returns on nominal returns. 
Table 8: Regression of Real Returns on Nominal Returns

\begin{tabular}{|c|c|c|c|c|c|c|c|c|}
\hline Period & & $g$ & $b$ & $\mathrm{R}^{2}$ & $\rho_{1}(e)$ & $\rho_{2}(e)$ & $\rho_{3}(e)$ & $\mathrm{T}$ \\
\hline \multirow{2}{*}{ 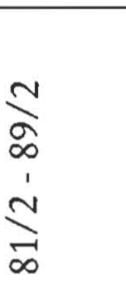 } & Begin & $\begin{array}{l}-0.033 \\
(-6.41)\end{array}$ & $\begin{array}{l}0.969 \\
(6.41)\end{array}$ & 0.58 & 0.030 & $0 . \overline{172}$ & 0.352 & 34 \\
\hline & End & $\begin{array}{l}-0.033 \\
(-6.39)\end{array}$ & $\begin{array}{l}0.968 \\
(6.39)\end{array}$ & 0.59 & 0.160 & 0.120 & 0.408 & 34 \\
\hline \multirow{2}{*}{$\begin{array}{l}+ \\
\stackrel{亠}{\infty} \\
\dot{\infty} \\
\stackrel{\infty}{\mid}\end{array}$} & Begin & $\begin{array}{l}0.0026 \\
(0.31)\end{array}$ & $\begin{array}{l}0.2519 \\
(1.15)\end{array}$ & 0.036 & 0.386 & 0.219 & 0.382 & 38 \\
\hline & End & $\begin{array}{l}0.0038 \\
(0.41)\end{array}$ & $\begin{array}{l}0.225 \\
(0.93)\end{array}$ & 0.024 & 0.229 & 0.224 & 0.252 & 38 \\
\hline
\end{tabular}

Source: Author's calculations from Treasury bill data. $g$ and $b$ are coefficients of Equation $9, R^{2}$ is coefficient of determination, $\rho$ 's are autocorrelations of residuals from 1 to 3 , and $T$ are the number of observations. T-statistics are in parenthesis.

Table 8 is a direct test of the hypothesis that real returns are constant over time. Real returns are regressed on nominal returns as specified by Equation 9 above. The results are still compatible with what is obtained from the previous two tables. They show that real returns change over time for all sample periods, except the end of period of the second sub-sample. This gives us genuine results for the data from the end of the second sub-period.

There is only one situation that appeared anomalous, as discovered above. Autocorrelations of changes in purchasing power showed that previous changes in purchasing power were not important in predicting its future changes for the end of the second sub-period. However, it is found that this is the period for which the market is efficient. It was hypothesised that, given globalisation at present, international prices may be important in influencing domestic prices. The analyses are conducted in the appendix to this study (Appendix 2) and it is found that US prices influence domestic prices. When they are incorporated into the equations they yield consistent results and still indicate that the market is efficient and US prices are taken into account. The other sub-periods still showed that the market is inefficient and their results are, therefore, not presented in the appendix. There is also a long-run equilibrium between South African and US prices, which further supports results of the analyses above. The conclusion is, therefore, that there are no inconsistencies in the findings, but global forces became increasingly important during the Stals period. 
This section has dealt with efficiency of the Treasury bill market. It is found that the market is becoming increasingly efficient for certain sets of bills, namely, those issued at end of months. It is thus important for the government to refrain from intervening in the market. The following section considers the specific behaviour of prices in the market.

\section{Price behaviour in the primary market}

This section looks at how prices behave in the South African primary Treasury bill market. Average values of discount rates on 91-day Treasury bills from the SARB Quarterly Bulletins are used. These are weekly average values because the South African government auctions its bills on Friday of every week, as explained before. This means that at any point in time bills that were issued 13 weeks before will be maturing. As a result there are always bills that mature 1 week apart from each other. Due to this weekly issuance of bills, at every point in time there is approximately 13 sets of bills with 1-week maturity differential. Data used range from January 1981 to October 1998. Years earlier than 1981 are excluded because the market was not as active as it was from the early 1980s.

In order to undertake the analysis effectively raw data are transformed into yields to maturity from the date of issuance of any particular bill. The following formula is used to compute yields to maturity as used by Park and Reinganum (1986):

$$
Y_{m t}=\frac{365}{m} \ln \frac{100}{B_{m t}} \ldots(11)
$$

$\mathrm{Y}_{\mathrm{mt}}$ is the annualised continuously compounded yield to maturity, $m$ is days to maturity, and $\mathrm{B}_{\mathrm{mt}}$ is a price at time $t$ of a bill that has $m$ days to maturity and pays R100 at time $t+m$. In order to analyse yield differentials of bills maturing at different times one needs to choose 1 week as a momeraire. The last week of each month was, therefore, chosen as a standard week in relation to which maturity differentials are calculated. The choice of week is arbitrary and it does not affect results as they depend on differences computed from adjacent bills. Thus, for each month end observation, all other bills were sorted according to remaining time to maturity and yield differentials of bills maturing 1 week apart were computed. Those bills whose maturity dates fall during the months were classified as 'within-months' bills. Those bills whose maturity dates fall at the turn of 
months were classified as 'turn-of-months' bills. Thus, if yield spread of two bills was generated from those bills classified as within-months then they were referred to as 'within-months' differences. Yield spreads resulting from last week of the month bill and first week of the following month were classified as 'turn-of-months' differences. Means of turn-of-months differences and that of within-months differences were, therefore, computed and their differences were examined, in basis points. Basis points are used in order to avoid dealing with negligible numbers with many decimal places, which tend to be difficult to interpret. A basis point is calculated as a one hundredth of 1-percent as explained by Frost and Hager (1990: 164) and Mishkin (1982: 68) i.e. 0.01-percent or 0.0001 . Yield differentials were, therefore, divided by a basis point to yield more manageable values. The spreadsheet from Excel was used to conduct this analysis and results are shown on Table 9.

Table 9: Average Annualised Yield Spreads between Pairs of Adjacent Treasury bills that Mature 1-Week Apart (1981-1998)

\begin{tabular}{|c|c|c|c|c|c|}
\hline $\begin{array}{l}\text { Classification of } \\
\text { Treasury bills }\end{array}$ & Mean & $\begin{array}{l}\text { Z-test } \\
\text { Probability }\end{array}$ & $\begin{array}{l}\text { T-test } \\
\text { within- } \\
\text { months }\end{array}$ & $\begin{array}{l}\text { T-test } \\
\text { September } \\
\text { /October }\end{array}$ & $\begin{array}{l}\text { No. of } \\
\text { Observatio } \\
n s\end{array}$ \\
\hline Within Months pairs & $\begin{array}{l}0.57 \\
(31.21)\end{array}$ & 0.31 & 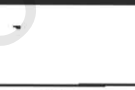 & - & 714 \\
\hline December/January & $\begin{array}{l}7.91 \\
(23.76)\end{array}$ & 0.07 & 0.16 & 0.49 & 18 \\
\hline January/February & $\begin{array}{l}-4.36 \\
(18.02)\end{array}$ & 0.84 & 0.28 & 0.03 & 17 \\
\hline February/March & $\begin{array}{l}6.61 \\
(25.19)\end{array}$ & 0.13 & 0.21 & 0.42 & 17 \\
\hline March/April & $\begin{array}{l}-3.08 \\
(33.56)\end{array}$ & 0.15 & 0.63 & 0.22 & 17 \\
\hline April/May & $\begin{array}{l}4.94 \\
(20.37)\end{array}$ & 0.53 & 0.19 & 0.30 & 18 \\
\hline May/June & $\begin{array}{l}-0.35 \\
(15.05)\end{array}$ & 0.53 & 0.80 & 0.10 & 18 \\
\hline June/July & $\begin{array}{l}-5.25 \\
(20.04)\end{array}$ & 0.86 & 0.24 & 0.03 & 18 \\
\hline July/August & $\begin{array}{l}11.46 \\
(36.77)\end{array}$ & 0.09 & 0.07 & 0.35 & 18 \\
\hline August/September & $\begin{array}{l}13.20 \\
(53.84)\end{array}$ & 0.14 & 0.16 & 0.34 & 18 \\
\hline September/October & $\begin{array}{l}7.98 \\
(15.34)\end{array}$ & 0.01 & 0.03 & - & 18 \\
\hline October/November & $\begin{array}{l}8.63 \\
(40.50)\end{array}$ & 0.18 & 0.14 & 0.47 & 18 \\
\hline November/December & $\begin{array}{l}2.2 \\
(14.57)\end{array}$ & 0.26 & 0.32 & 0.12 & 18 \\
\hline
\end{tabular}

Source: Author's calculations from Treasury bill data. The annualised yield spreads are measured in basis points and are computed by calculating yield to maturity of bills that mature 1 week apart and subtracting the yield to maturity of the bill maturing 1 week earlier from that of the bill maturing 1 week later. If two bills mature within the same calendar month they are classified as within-months bills, and if they mature across the months they are classified as turn-of-months bills. There are 12 turn-of-month classifications and 1 within-months classification. Standard errors are in parentheses. 
From Column 2 of Table 9 it is clear that absolute values of all mean spreads of bills maturing across months are higher than the average of mean spreads of bills maturing within months, in absolute values, except for the May/June pairs. This means that there is special treatment or preference for bills maturing across month ends in relation to those maturing within months. Apart from that it is clear that average yield spread of the August/September bill is highest and rests at 13.20 basis points and is 23 times as high as average yield spread of the within-months pairs which is 0.57 basis points. Comparing it with the November/December average yield spread it is 6 times as high. It is also 1.7 times as high as both the December/January and September/October bills which are 7.98 basis points each, and also 1.15 times as high as the average yield spread of the July/August bill which is 11.46 basis points. The January/February average yield spreads rests at -4.36 basis points, February/March at 6.61 basis points, March/April at -3.08 basis points, April/May at 4.94 basis points, and June/July at -5.25 basis points. This situation is outstanding and deserves close attention, as it is unusual in Treasury bill markets, which are generally expected to be highly efficient. It suggests that Treasury bill market participants do not arbitrage away differences in yields of bills maturing at different periods, notably within months and end of months.

Column 3 of Table 9 contains probabilities of Z-test for the null hypotheses that individual means of the turn-of-month observations and that of the within-months observations are individually equal to zero. The results show that the September/October average yield spread is significantly different from zero at a 1percent level. The December/January and July/August average yield spreads are both different from zero at a 10-percent level. The remainder of the average yield spreads is not significant either at 5-percent or 10-percent levels.

Analyses of variance (ANOVA) were also conducted by using simple one-way ttests for differences in means to find out whether means of turn-of-months bills are significantly different from within-months average. Results of this operation are shown in column 4 of Table 9. This time it is found that the September/October average yield spread is significantly different from the within-months pairs at a 5-percent level. The July/August average yield spread is different from within-months average spread at a $10-$ percent level. The remainder of average yield spreads are not significantly different from the average yield spread of the within-months bills. 
Column 3 of Table 9 shows that the average yield spread of the September/October bills is significantly different from zero at a 1-percent level. It is, therefore, interesting to know the significance of the difference between that month's average yield spread and that of other turn-of-months yield spreads. The results of such comparisons are documented in column 5 of Table 9. The findings are that the September/October average yield spread is significantly different from both the January/February and June/July average yield spread at a 5-percent level. The remainder of turn-of-months average yield spreads are not significantly different from the September/October average yield spread either at the 5-percent or the 10-percent levels of significance.

Given the smaller number of cases where turn-of-months average yields are significantly different from within-months average yield spread it is highly likely that turn-of-months average yield spreads are simultaneously insignificantly different from within-months average yield spread. In addition to that care has to be taken in interpreting results of the significant cases given the limited number of observations from turn-of-months average yield spreads. These observations are listed in the last column of Table 9.

The results found in column 2 of Table 9 suggest that there is a dramatic upwardjump in yields when they cross the July/August and August/September months. However, the latter jump is stronger than the former, but they are both above 10 basis points. The December/January, February/March, April/May, September/October, October/November, and November/December yield spreads also show an upward jump but less than 10 basis points. The latter jump is the lowest at 2.2 basis points. The remainder of the turn-of-months jumps are negative and all are less than 10 basis points with the May/June jump being the lowest in absolute value at -0.35 basis points and even lower than within-months average. The negative average differences are not inconsistent with positive average differences. This is because data used are weekly and the last week of the month does not necessarily include the last day of the month. In that case the last day of the month falls in the first week of the following month, which naturally generates a negative average difference. This is just a result from the kind of data used rather than inconsistency in the results. In Park and Reinganum's study all average differences are positive. This has implications for potential of the government to generate more revenue 
from marketing its bills and improving the management of cash as well as reducing the costs of borrowing.

There is a remarkable jump as we move across the August /September months in relation to any other jump on the table above. This is a typical case of the behaviour of the yield curve as it crosses calendar months in South Africa. The insignificance of this turn-of-months average yield spread when compared with the within-months average yield spread was startling. This necessitated a close examination of data. The findings revealed that most of the observations were low and could not influence the average value of those observations. It was found that the August/September 1998 yield spread was 208 basis points and was the highest ever experienced for that pair of months in the whole sample period. This constituted a significant outlier to influence the average value of all other observations. Therefore, much faith cannot be put in this turn-of-months observation, as it is unusual. This is in contrast to the July/August and September/October averages, which are both significant at 10-percent and 5-percent levels of significance, respectively.

This unusual jump has, however, happened during the time when there are significant changes in the operational procedures of the South African monetary system, as outlined above. It may well be the case that these changes have affected bidding behaviour of participants or even the composition of bidders in the auction and this may account for this sudden change in the behaviour of yield spreads. If this is the case it may also be necessary for the South African government to alter its methods of issuing bills to take advantage of these new changes in the market. ${ }^{5}$

This section has dealt with specific price behaviour of bills in the primary market. It is found that bills maturing at the end of months have higher prices than those maturing within the months. This is considered important for the way the Treasury markets its securities to obtain maximum possible revenue. The following section tackles the issue of designing effective auctions for Treasury securities.

${ }^{5}$ A detailed discussion to this effect will be provided in the next chapter. 


\section{Designing effective auctions: Taxpayers' boon or curse?}

Much of the debate at present has focused on which auction procedure is superior, uniform-pricing or discriminatory auction. Theory predicts that uniform-price auctions are revenue-superior relative to discriminatory auctions as long as there is no collusion in the market. It also predicts that uniform-price auctions are more susceptible to collusive practices than discriminatory auctions. This suggests that in cases where there is collusion in the market then uniform-price auctions are revenue-inferior.

The conclusion that discriminatory auctions are less susceptible to collusion is based on the assumption that any collusive arrangement should be focused on keeping prices downwards and any deviation from the agreed price will make the relevant party benefit in relation to others. In that kind of set-up discriminatory auctions, of course, are less susceptible to collusion since it is more likely to break down. On the other hand, Friedman's argument that uniform-price auctions are less susceptible to collusion is probably based on the same premise that any collusive arrangement should be focused on keeping prices downwards. Any deviation from the agreed price will make the relevant party win the auction, but it would then pay the price agreed in the cartel arrangement. That holds only in cases where the defecting party leaves some amount of supply to the members of the cartel. In that kind of situation a collusive arrangement, of course, is more likely to break down, as in the case of discriminatory auctions. This argument is centred on explicit collusion because the motive of cartel members is to corner the market collectively and charge higher prices in the secondary market. However, in the presence of antitrust laws implicit collusion is more likely to prevail. In addition to that members to an explicit collusion are more likely to defect if costs of being caught are high in both auction formats.

If one bases the arguments on cornering the market, as emphasised in the theoretical literature, and considers Friedman's argument in relation to that widely held in auction theory, it would seem that the two auction formats are characterised by collusion or its breakdown depending on how one approaches the problem. Then, one may dismiss the argument of which of the two is more susceptible to collusion and focus the analysis on how low the price can be fixed in either of the two arrangements in case there is collusion. Alternatively, one may as well ask the question of how the two auction systems can be ranked in terms of revenue in case there is collusion. 
Empirical evidence has already shown that uniform-price auctions, in general, are revenue-superior to discriminatory auctions. But evidence is limited of the case where there was collusion in the market and uniform-price auctions were revenue-inferior to discriminatory auctions. The study by Simon (1994b) documented that the US Treasury department lost potential revenue when it experimented with uniform-price auction over the period between 1973 and 1976, but he did not relate this to the existence of collusion. He concluded that it is because the demand curve did not shift to the right enough to compensate the Treasury for loss in revenue resulting from change in auctioning procedure and awarding bills at a price bid by the highest losing bidder. Friedman undertook the same kind of study for the period between 1973 and 1974 and found that uniform-price auctions yielded greater revenue than discriminatory auctions. The study by Umlauf (1993) shows that uniform-price auctions promised to be revenuesuperior even in the case where there was some evidence in favour of collusive bidding; and apparent superior information among the largest bidders. What does this imply for the literature on auction theory and institutional arrangements for auctions?

This section attempts to answer the apparent anomaly in the real world that uniform-price auctions seem to be superior even in the case where collusion exists. In cases where there is collusion theoretical analyses indicate that revenue from uniformprice auction will be lower. This is so because bidders' strategy is to fix the price downwards and let one of the members in a cartel bid a high price so as to guarantee winning the auction. However, upon winning, the institutional arrangement of the auction entitles the highest bidder to pay the price bid by highest losing bidder. In that case auction theory would predict that it is the price fixed by other members of the cartel which is more likely to be very low. On the other hand, if it is a discriminatory auction, members of the cartel still agree to fix price downwards. However, price in this case will not be as low as it would be in the case of uniform-price auction. This is because there is fear that other participants in the market can bid more than that and thus win the auction. Therefore, the average price from the discriminatory auction would seem to be higher than that in uniform-price auction in the existence of collusion.

This is not the case if one considers it from a game-theoretic point of view. From this point of view results should be the converse of what is concluded above. From a discriminatory auction perspective it is concluded that average price seems to be higher. 
This does not mean that revenue to the Treasury will also be higher. Consider a case where larger bidders form a cartel and the remainder of the market is so small as to have no significant influence on the outcome of the auction. Those large bidders are now more concerned about the entire supply rather than the price smaller bidders will command. In that case it is, therefore, rational for them to allow small bidders to undercut them and win the auction. In doing that they will only win a small portion of the entire supply thereby leaving the remainder to the cartel. The cartel will, therefore, reap the remainder at a lower price (higher yield). They will, however, charge monopoly prices in the secondary market as they hold a greater percentage of the entire supply. In that way average revenue from discriminatory auctions will be lower than that from uniform-price auctions even in the presence of collusion. This is the complete opposite outcome from that described above in the case of discriminatory auctions. On the other hand, if one looks at uniform-price auctions results are once more in stark contrast with what auction theory maintains. From the above discussion on auction theory it is concluded that average price will be low in the case of uniform-price auction and revenue will also be lower. In contrast, if cartel members allow one of their members to bid very high so as to guarantee winning the auction, then the average price and revenue will be higher. This is because upon winning the relevant bidder has to take some of the supply already available in the market, as he has to win on behalf of the cartel members, leaving the remainder to other bidders to share. Bidders other than members of the cartel are more likely to bid more than the cartel is bidding, but less than the price bid by the winning member of the cartel. The winning member will, therefore, pay a price bid by other bidders who are not members of the cartel, which is higher than that bid by members of the cartel. Thus, on average the price and revenue is higher than they were initially believed to be. This result generally holds if the entire supply is less than demand. Even more so, in the case of uniform-price auctions, bidder participation tends to be broadened thereby guaranteeing higher prices than that bid by members of the cartel. Broadening bidder participation also has an effect of increasing demand and pushing the bids upwards.

Game-theoretic analyses employed above are more in favour of revenuesuperiority of uniform-price auctions, even in the presence of collusion in the market. This can explain more plausibly the anomaly faced in the real world where empirical results show that uniform-price auctions are revenue-superior yet many governments 
continue using discriminatory auctions to market their securities. The response from game theory to the study by Simon (1994b) is more likely to be that of total supply exceeding demand thereby suppressing the bids downwards. In this particular case, the rule of uniform-price auction changes to awarding securities at the lowest winning bid, (because all bids win!) ${ }^{6}$, which means that revenue will accordingly be lower. This does not disqualify revenue-superiority of uniform-price auctions over discriminatory-price auctions.

The remaining unanswered question revolves around why the majority of countries around the world use discriminatory auctions rather than uniform-price auctions, given the latter's simplicity and revenue-superiority. Auction theory has always claimed that uniform-price auctions are more susceptible to collusion than discriminatory auctions. Many countries, therefore, would not be willing to be under such a trap given limited skills the authorities have in detecting collusion. Despite anti-trust laws it is possibly very difficult and expensive in this case to rule that participants have colluded, in the absence of explicit evidence. One need only recall how much money was lost in the US on the case of International Business Machines (IBM) with the final result being the cancellation of the case, as it was becoming too expensive. The best strategy under these circumstances is, therefore, to use discriminatory auctions, which are believed to be less susceptible to collusion. After all the governments related to here employ auction theorists to give them advice. Thus, it follows naturally that they will adopt discriminatory-price auctions.

Some industrialised countries and a few developing countries have, however, experimented with uniform-price auctions but eventually reverted back to discriminatory auctions, even with clear indications that uniform-price auctions were revenue-superior. These countries include Belgium, France, Italy, Gambia, Mexico, and Tanzania (Bartolini \& Cottarelli, 1997). For these countries it may well be the case that government agents collude with bidders and make money from government assets. This may hold to a large extent in the case of Italy, as it has a reputation for bureaucratic corruption. In addition to that all countries mentioned above are not in the top 20 of the corruption perceptions index for 1997 meaning that they are characterised by high level corruption. For other developing countries it is reasonable to assume that they use discriminatory auctions

\footnotetext{
${ }^{6}$ This situation is analogous to an election candidate canvassing for a position alone. He always wins!
} 
because industrialised countries use them and they tend to follow the lead of developed countries. It is, therefore, not because of fear of collusion, per se, but because they follow the strategy of laggards. It is reasonable for one to do what many other people are doing in order not to lose alone in case there is a loss, just as developing countries compete over reducing their deficits to 3-percent of GDP as in developed countries. This banctexagon effect ${ }^{\text {vii }}$ does not have good implications for generating revenue for the Treasury. Paradoxically, these are countries that have high levels of public debt but they are not willing to follow a simple strategy that would also lower costs of borrowing and financing their debts, and broaden bidder participation in the market.

This section has entertained the question of designing effective auctions for Treasury securities. It holds a completely different view to that generally held and argues that uniform-price auctions are revenue-superior even in the case of collusion. This is in contrast to auction-theoretic predictions.

This chapter has examined efficiency of the Treasury bill market in South Africa. It has found that the market was grossly inefficient during the 1980s. There are, however, indications that the market may be becoming more efficient for certain sets of bills during the Stals era. It has also been found that behaviour of prices in the market allows the Treasury to improve cash management and lower costs of borrowing. Finally, gametheoretic analysis is used to explain the apparent anomaly between auction theory and empirical findings. The conclusions reached in this study are consistent with empirical evidence. The following chapter deals with policy proposals in view of the conclusions reached in the present chapter. 


\section{Chapter 5: Implications of Findings for Policy}

This chapter looks at implications of the findings, in the previous chapter, for cash management by the Treasury. It also highlights proposals that can be followed to improve efficiency of cash management by the central government and operations of the Treasury bill market. This is very important in the globalised economy where the efficiency of the public service is very important in preserving competitiveness.

\section{Cash balance optimisation}

The first section of Chapter 4 looked at the management of cash balance by the Treasury. It was found that significant improvements have been made during this decade. It is, therefore, important that the Treasury be given the necessary freedom to undertake its cash management task efficiently without intervention. Most tasks related to cash management were done by the SARB and it is good that they be put under the control of the Treasury, as it is happening at present. This process has resulted in more meaningful cash forecasts and it has enabled the introduction of daily forecasts of cash flow.

The following section discusses policy implications related to the operations of the Treasury bill market.

\section{Market efficiency}

The second section of Chapter 4 has looked at the efficiency of the Treasury bill market following work by Fama (1976). The basic assumption employed was that market participants maintain a constant level of real returns on their bills. It was also hypothesised that they take into account past changes in purchasing power in assessing nominal rates of returns. The implication of these two assumptions is that market participants take into account all the information relevant at a point in time in setting the nominal rate of return at the beginning of any period. This means that changes in nominal returns should not explain any variation in the level of real returns, but it should be able to explain a fair amount of variation in the expected level of inflation. In an attempt to test these hypotheses autocorrelations of changes in purchasing power were generated for successive periods. The assumption of non-zero autocorrelations generally held for data other than that from the end of the second sub-period for which the market is found to be efficient. However, international prices were hypothesised to be important in an increasingly globalised world. 
These results are in direct contrast with those of Fama (1976) where he found that the US market for Treasury bills was efficient in the sense that nominal rates of return reflected all the information available in the market about the future level of prices for all categories of bills considered. Fama (1976), however, found that for the period when there were price controls in US the market tended to be inefficient and market participants were unable to incorporate all information when predicting future spot rates. This was the time during the early 1970s when there was an oil price shock. This result shows that it is very important for the Treasury bill market to be opened to everybody else willing to participate and that there should not be government intervention in terms of manipulating the relevant variables. This is also consistent with a need to avoid the existence of collusion in the market. General understanding is that if there are only a few participants in the market it becomes easier to form and enforce cartels which then has negative results on efficiency of the market and the well-being of the society (Phlips, 1995).

The size of the CPD and SARB own tenders in the auctions might have influenced the efficiency of the market during the 1980s. It is thus important that the government should refrain from interfering with the Treasury bill market.

This section emphasises the view that the government should refrain from intervening in the market and should also allow broadened participation in the market if its operations are to be improved. The following section presents policy implications regarding price behaviour of bills in the primary market.

\section{Price behaviour}

The third section of Chapter 4 looked at specific behaviour of prices in the primary market. To undertake the analysis continuously compounded yields to maturity were computed and observations were sorted according to remaining time to maturity for each month end observation. Yield differences from bills maturing 1 week apart from each other were computed. As explained in Chapter 4 those bills maturing across the month ends were called end-of-months bills and their differences were called end-ofmonths differences. The averages of yield spreads were computed for both end-ofmonths differences and within-months differences and differences in their means were assessed. 
The results in the present study differ remarkably from those of Park and Reinganum (1986). They find average yield spreads of within-months observations of 4.17 and 2.56 basis points for the 31-60 and 61-90 days maturity ranges. The present study is more concerned with the 61-90 days maturity range as it is the one used here. It is clear that 2.56 basis points are greater than 0.56 basis points in absolute terms. In addition to that the 2.56 basis points is the smallest average yield spread compared to the rest of end-of-months average yield spreads. This is in contrast to what the present study obtained where the May/June average yield differential was actually smaller than the within-months average in absolute value. Therefore, in Park and Reinganum's study turnof-months average yield differentials are clearly greater than that of within-months average yield spreads. This also clearly indicates that there is a stronger preference for bills maturing at the end of the months in relation to those maturing within the months.

Another difference between this study and Park and Reinganum's study is related to differences in average yield spreads between within-months bills and end-of-months bills. These authors use the multiple comparison analysis of differences in means suggested by Scheffe (1959). The results from that iest show that the December/January, January/February, and September/October turn-of-months pairs are simultaneously different from the within-months pairs at a 5-percent level of significance for the entire sample period. Among these three pairs the yield spread of the turn-of-year is greatest at 28.33 basis points. The yield spread for the December/January pair is nearly twice as large as for the September/October and about 1 and 1.5 times as great as the January/February pair. Based on the simple t-tests yield spread of the December/January pairs is significantly greater than that of either the January/February or September/October pairs. The authors also divided the sample period into 4 equal subperiods to test the stability of differences in means over time, still using the above multiple comparison test. In the first three sub-periods, average spread of the December/January pair was significantly different from the average spread of the within months pairs. The mean of the January/February pair was different from the mean of within-months pairs in the second and the third sub-sample, and mean of the September/October pair differed from mean of within-months pairs in the first and second sub-sample. 
In contrast to this finding this study does not use multiple comparison tests but uses simple t-tests to assess differences in means between end-of-months pairs and within-months pairs. It finds that only the July/August and September/October yield spreads are significantly different from within-months average yield spreads at 10- and 5percent levels of significance, respectively. The December/January average yield spread, found to be the highest in their paper, is only significantly different from zero at a 10 percent level and is not significantly different from the mean of the within-months differences. It is only the September/October yield spread that is compatible with their findings. However, among other turn-of-months pairs the September/October pair is only significantly different from the January/February pair at a 5-percent level.

The above findings have implications for cash and debt management by the Treasury as well as government financial decisions in general. This behaviour of yields implies that the government will be able to increase the amount of revenue it gets from marketing bills for cash management by issuing more bills maturing at the end of months. This equally holds for debt management where the government will be able to lower the costs of borrowing by issuing these bills, to finance short-term expenditure, that mature at the end of months.

Recommendations made above would not hold to the same extent for all cases where yield spreads are greater than of the within-months observations, in absolute value. The results in this study, as explained before, showed that only the July/ August and September/October yield spreads are significantly different from within-months average spread at 10- and 5-percent levels, respectively. This means that differences between month-end yield spreads and within-months yield spreads are genuine and guarantee superior revenue for the government if it issues more bills maturing at the end of these periods. In using this strategy of altering supply of bills maturing in different periods the government would, therefore, have to put much emphasis on those two pairs of turn-of-months periods. The differences in means suggest that the government is not getting the maximum possible revenue from the issuance and marketing of its Treasury bills and it can thus be argued that there is scope for improvement. This also implies that the government is not managing its cash and debt efficiently if it is not following strategies outlined in this study. It means that financial managers are failing to determine the appropriate payment schedule for efficient cash management and proper maturities 
for short-term securities for efficient debt management. Strategies outlined here will, however, have to be practised with caution as they may yield negative than expected results for the Treasury, thereby imposing a burden on taxpayers. This can happen in a case where the government increases supply of relevant bills by more than is necessary thereby diluting the yield differences by affecting prices. Any money lost through mismanagement should be made up from the taxation of individuals and firms in the economy, however small the amounts involved are. The study by Simon (1994a) showed that differences in relative supplies of 13-week and 12-week bills have significant and economically meaningful effects for the US economy.

This section emphasises that the government should increase the supply of bills maturing at the end of months, for there appears to be an excess demand for those bills in response to the national payment system. This will help to increase revenue from marketing its securities. Care should be taken, however, not to increase supply by more than appropriate. The following section presents policy implications related to gametheoretic analyses presented in the previous chapter.

\section{Game-theoretic analyses}

\section{Empirical results}

The results from the second section of Chapter 4 show that although the market for Treasury bills in South Africa was grossly inefficient in the past, there are indications at present that the market is becoming more efficient than ever before. This was confirmed by results from end of period data of the second sub-period. Results for that sub-period were stable and consistent with regard to different specifications of the model.

There are indications that market participants started considering maintaining stable real returns and considering all relevant information at a point in time from the period the governor of the SARB was changed in 1989 to the present. As a result the market was efficient, but that only held for data from end of months observations. This means that market participants are concerned about maintaining constant real returns for bills issued during the last week of the month and that is what the market has maintained 
throughout the period.' This situation does not hold for data from beginning of the period observations implying that participants disregard the concept of constant real returns for these bills and any other relevant information available.

This added feature of stable real returns has an additional implication for strategies of the government in making its financial decisions, including cash and debt management. Given the concept of stable real returns over time one may use gametheoretic approach once more to see whether there can be an improvement in the positions of both the Treasury and market participants. This is indicated in Table 10 for the September/October pairs. This is a typical case of payoffs in basis points rounded off to the nearest tenth.

Table 10 : Treasury-Bidders Strategies Payoff Matrix

\begin{tabular}{|c|c|c|c|}
\hline Parties & \multicolumn{3}{|c|}{ Bidders } \\
\hline \multirow{3}{*}{ 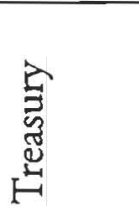 } & Strategies & Stable & Variable \\
\hline & High & $0<x<8,26$ & $0<x<8 ; 16$ \\
\hline & Low & $8 ; 26$ & \\
\hline
\end{tabular}

Table 10 indicates strategies available to the Treasury and market participants for the September/October pair as revealed by the empirical analyses. Results show that the situation prevailing at present is the one in the cell highlighted in red, that is, the bottomright cell. According to empirical findings the market is inefficient in that region and market participants do not maintain constant real returns on their Treasury bills. The result of that situation is an average real return of 16 basis points over time. This is because inflation erodes the real returns since participants do not take it into account in setting nominal returns of bills at maturity. The government at that region gets 8 basis points in yield differentials, which means a higher price to the Treasury. The Treasury certainly benefits in this case while market participants get low real returns from their bills. The government will benefit even more if it follows a strategy of supplying more bills that mature across the September/October months. The Treasury financial managers in that case generate more revenue than before. As a result of that they move one step further to the upper-right cell of Table 10, highlighted in yellow. This time the Treasury still benefits without any benefit accruing to market participants in terms of

\footnotetext{
${ }^{7}$ Constancy of real returns does not imply market efficiency; the market could still be efficient even if real
} returns were not constant over time. 
higher positive real returns, that is, real returns remain at a 16 basis points level over time while the government manages to improve its revenue. On the whole, there is an improvement in the well-being of the society since increased revenue should have some offsetting impacts on the taxes, which would otherwise have to be collected from taxpayers. Results up to this point apply only if market participants are undertaking a strategy of non-constant real returns over time as they do with bills maturing at the end of the months. For this set of bills our data shows that they were issued at the beginning of the months and are the one for which the market is inefficient.

If market participants are rational, they will realise the benefits of making the market efficient by considering all relevant information and adopting the strategy of constant positive real returns over time. This, of course, is the case assuming that participants in the market are making their decisions freely without any government interference as happened during the 1980s in South Africa and during the early 1970s in the US. In that case, as is happening to some extent during this decade, market participants will be able to incorporate all relevant information in predictiong future spot rates thereby rendering the market efficient. The results showed that in that case real returns over time are 26 basis points. Clearly this is preferable to the previous two situations. Market participants will, therefore, behave rationally and undertake a strategy of constant real returns over time, reaping the benefits thereof. This is what is happening in South Africa at present for bills issued at the end of the months. Market participants have probably realised that they can derive more benefits by adopting that strategy. The Treasury in this case maintains a constant level of real yield differences and also a constant real value of its revenue over time. The solution in this case is, therefore, the upper left cell of Table 10, highlighted in green. In this case both the Treasury and market participants benefit from participating in the market. If market participants perceive more and more benefits from this strategy over time and if there is no government intervention to preclude the efficient functioning of the market, one would reasonably expect the South African Treasury bill market to be completely efficient for all categories of Treasury bills in a short period. This last strategy is also Nash equilibrium as it turns out to be a saddle point and, therefore, a stable strategy. No participant to this game has an incentive to alter their strategy unilaterally as this would result in loss of benefits. It is thus important that the government should leave the 
market alone to perform its functions. It is even more important for Treasury's debt and cash management functions as it guarantees a stable real value of revenue over time.

The Treasury in this case can be modelled as a revenue-maximising monopolist practising perfect price discrimination, that is, first-degree price discrimination. There will be a limit regarding the magnitude of the increase in supply of certain bills in order to maximise revenue. From Table 10 it is clear that the difference between the two adjacent bills should range between 0 and 8 . There will be some threshold $(\mathrm{x})$ between, below which differences should not fall for those strategies to remain superior to the bottomright strategy.

This subsection brings together the results from the analysis of market efficiency and price behaviour in the market and argues that there is a stable equilibrium in dealings between the Treasury and market participants. It also argues that this equilibrium improves the welfare of both the Treasury and bidders, that is, it is Pareto efficient. The following subsection presents policy implications regarding designing effective auctions.

\section{Uniform-price or discriminatory auctions?}

The discussion in this study has indicated that uniform-price auctions are superior to discriminatory auctions even in the presence of manipulative practices. This view was held partially by Chatterjea and Jarrow (1998), but not in the way it is explained in this study. Friedman appears to have had the view right but for the wrong reasons. It is pointed out, however, in this study that the conclusion held here is also compatible with the empirical findings about revenue-superiority of uniform-price auctions to discriminatory auctions. Goswami, et al. (1995) present an experimental model which shows that uniform-price auctions result in self-enforcing collusive arrangements but they do not experiment within a framework where there are secondary markets which may well alter their conclusions. They also appear to have been influenced by auctiontheoretic conclusions.

This has implications for the Treasury in selecting the kind of auction procedure to market its marketable securities. It seems mechanical that most governments around the world use discriminatory auctions while uniform-price auctions are clearly superior and simple to conduct as well as broadening investor participation. For developing countries, whose costs of borrowing constitute a large proportion of expenditure, 
reducing costs of borrowing would seem the most attractive thing they should do. However, it appears that they follow the strategy of laggards and just do what developed countries are doing.

For South Africa the situation is even worse because, as noted above, there is no limit regarding the maximum percentage of the total supply each participant can hold in the market. This implies that cornering the market is lawful in South Africa. This has an effect of restraining activity in the secondary market because if one firm happens to hold the entire market supply it can then charge monopoly prices to secondary market participants. Even more so, those who have entered into agreements with clients to supply a given amount of bills once they are issued will not be able to do so and will be forced to purchase them from this monopolist who will then charge exorbitant prices. It is, therefore, suggested that there be a limit on the maximum percentage of the entire supply each participant is allowed to hold.

The other problem in South Africa is that offshore investors are not allowed to bid for themselves in local auctions. Rather they are required to appoint an authorised domestic agent who will then bid on their behalf. This does not allow broadening bidder participation in the market and is more likely to influence collusion. It effectively restrains much needed competition in the market to guarantee high revenue for the Treasury through auctioning its securities. It is, therefore, important to allow foreign investors to participate in the market. Since they are more likely to be bigger than domestic participants are it is, as suggested earlier, better to set a maximum percentage of the entire supply each bidder can hold in the market.

The conclusion in this study regarding the superiority of uniform-price auctions compared to discriminatory auctions would suggest that governments have to follow uniform-price auctioning procedure before even thinking about dealing with market manipulation. This is because they can be sure that uniform-price auction yields greater revenue than would otherwise be the case had discriminatory auctions been followed. Given the costs of enforcing antitrust laws this can be the first thing to do for developing countries, in particular. 
This subsection emphasises that it is better for governments to use uniform-price auctions than discriminatory auctions before attempting to deal with manipulatory practices in the market. For South Africa it is suggested that there be a limit on the maximum percentage of the entire supply each bidder is allowed to hold. It is also suggested that offshore investors be allowed to bid on their own, as it will broaden bidder participation and enforce much needed competition in the market.

In summary, this chapter has dealt with policy implications in view of results from Chapter 4. There are two major conclusions, with one being the main contribution to the South African Treasury bill market and the other being a contribution to auctiontheoretic literature. It is concluded that there is a saddle point in interactions between the Treasury and bidders in the market. It is also concluded that uniform-price auctions are superior even in the case of collusion and that governments should adopt them before even thinking about dealing with manipulatory practices in the market. The following chapter concludes the study. 


\section{Chapter 6: Conclusion}

This study has discussed the role of Treasury in promoting efficiency of cash management in South Africa. Any shortfall in expenditure should result in recourse to the market for funds and any surplus of funds should be invested to yield maximum revenue from interest. The objective of cash management is, therefore, to make sure that maximum interest earnings are obtained from invested surplus funds and minimum interest is paid on borrowed funds. In view of the two considerations this study has, therefore, concerned itself with two decision variables for cash management, namely, the cash balance and marketable securities. Chapter 2 reviews the theory related to cash balance optimisation and efficiency of the Treasury bill market as well as literature on revenue-superiority of different auction formats. Chapter 3 considers the South African situation and reviews cash management procedures by the South African Treasury as well as developments and operations of the Treasury bill market. Chapter 4 is concerned with empirical findings and analysis of problems. Chapter 5 presents policy implications related to the analysis in Chapter 4.

It is clear from the analysis in this study thai there have been improvements in the management of cash balance by the Treasury. This improvement has come about during a time when South Africa faces many changes in the economic world. On the one hand, there are pressures from the rest of the world of having to reduce deficits and public debt as percentages of GDP to acceptable levels in line with international practices. On the other hand, repayment of interest costs on debt accumulated prior to 1994 constitutes a large percentage of government expenditure so as to cause significant variations on financing requirement. All these factors have to be taken into consideration in determining payment schedule and maturity dates and choosing an acceptable level of cash balance to be kept in the Exchequer Account with the SARB. This has led to significant variations in the amount of bills the Treasury issues at specific times to meet high variations in outlays of the central government. Improvements made signify a best response to global changes by a developing country.

Interest earned on invested surplus funds should contribute to repaying some of interests costs accumulated before and should have a kind of offsetting impact on the level of taxes. Had there been no improvements outlined above South Africa would be in a situation where interest costs are always rising without any savings being effected in 
some way. This would more likely make taxes rise or more debt be accumulated to finance the already available debt. The situation is expected to improve when debt levels and deficits have been brought down to acceptable levels.

There is still more to be done on the side of the Treasury bill market regarding institutional arrangements. South Africa was previously characterised by heavy intervention by authorities in the monetary sector. The market was operating inefficiently during the De Kock era because of this factor, which included the establishment of public enterprises to facilitate interventions. There are indications of a complete change in operations of the market from the De Kock era to the Stals era. Operations are becoming more efficient and rates reflect market conditions to some extent. This is a situation that needs to be encouraged if South Africa is to be able to compete with other countries on the global front. Undue government intervention has to be retarded and markets should be left to operate to the benefit of society.

There is, however, a problem with institutional set up of the market in South Africa. In the first place there is no limit on the maximum percentage of the entire supply each participant has to hold in the market. The authorities are not concerned whether any of the participants corners the market or not. This would imply that cornering the market is legal in South Africa, in contrast to countries like US where the Salomon scandal was widely denounced. This certainly restrains activity in the secondary market and is not supportive of economic development. In countries like US one participant is not allowed to hold more than 35-percent of the entire share of Treasury bills. Market cornering is a serious offence there. South Africa as well has to consider placing a limit on the maximum percentage each bidder can hold in the market.

The present arrangements would appear to contradict the rule that bids are invited from any person or firm. If firms and persons are participating in the same market it is more likely that small bidders will be outperformed and will never be able to get supply they need. The arrangements as they there are at present are more likely to discourage participation by smaller bidders. An examination of auction results showed no indication of a non-competitive price or an average price at which smaller noncompetitive bidders are allocated supply. It is better, therefore, to invite and consider non-competitive bids from smaller bidders and allocate some supply to them. 
The other problem in the Treasury bill market is that offshore bidders are not allowed to bid on their own behalf. This tends to restrain bidder participation in the market and should also have an effect of suppressing prices downwards. It also influences the continuance of collusive arrangements by major bidders in the market. This is a major impediment of the proper functioning of the market and should be avoided.

Behaviour of prices in the market fairly reflects what happens in other countries except for a few cases of constant prices that may be a result of government intervention. This behaviour of prices has implications for cash management and lowering costs of borrowing. The Treasury can benefit more by reshuffling the issuance of its securities so that maturities coincide with end of months, for there appears to be specific preference for that period.

Game-theoretic analyses appear to be useful in resolving some of the problems and interactions between the Treasury and market participants. It is shown here that there exists a saddle point in dealings between the Treasury and bidders. At that point the solution is stable and positions of both the Treasury and bidders are improved, and the overall welfare of the society is also improved. This opportunity also has to be taken advantage of.

Uniform-price auctions appear to be safe to adopt because of their apparent revenue-superiority in relation to discriminatory auctions even in the case where collusion exists. This result is different from what is widely held by auction theorists and is more important for developing countries trying to reduce their debt levels. Studies indicate that a number of countries have used uniform-price auctions and found them to be revenue-superior but still reverted to discriminatory auctions. Those are, however, countries in which collusion in government agents and the private sector is common or once prevailed. This may, of course, make uniform-price auctions unattractive. The present study, however, concludes that uniform-price auctions are safe to adopt before even considering manipulative practices in the market. More research will be needed in future regarding the vulnerability of uniform-price auctions to corruption between bureaucrats and market participants. 
There is clearly still much to be done both in South Africa and in the area of auction literature. There is still a task of reconsidering auction theory on Treasury securities markets with secondary markets. It appears that conclusions reached at present are insufficient to explain what is happening in the real world. Most of the literature assumes aggressive bidding using prices and disregards bidding with the main intention being the entire supply in the market. Models should still be devised that concentrate on the quantity side of market adjustment. Regarding South Africa there is still much to be done in the area of devising institutional arrangements for the Treasury bill market. 


\section{Bibliography}

Back, K. and Zender, J. (1993), Auctions of Divisible Goods: On the Rationale of the Treasury

Experiment, Review of Financial Studies, Vol. 6: 733 - 764.

Ball, I. (1998), Modern Financial Management Practices; PUMA/SBO(98)8/FINAL, Paris: OECD.

Bartolini, L. \& Cottarelli, C. (1997), Designing Effectiue Auctions for Treasury Secunties;

Current Issues in Economics and Finance, Vol. 3(9: 1- 6), July, Federal Reserve Bank of New York.

Baumol, W.J. (1952), Transactions Demand for Cash: An Imventory Theoretic Approadb;

Quarterly Journal of Economics, Vol. 66(4): 543 -546.

Bickchandani, S. \& Huang, C. (1989), Auctions with Resale Markets: An Exploratory Model of

Treasury Bill Markets; Review of Financial Studies, Vol. 2: 311 - 339.

Bikhchandani, S. \& Huang, C. (1993), The Economics of Treasury Securities Markets; Lournal

of Economic Perspectives, Vol. 7(3): 117 -134, Summer.

Binmore, K. (1992), Fun and Games; D.C. Heath and Company: Massachusetts.

Bloch, E, (1964), The Treasury's Deposit Balances and the Banking System; Essays in Money

and Credit, Federal Reserve Bank of New York, pp 19 - 24.

Campbell, J.Y., Lo, A.W. \& MacKinlay, A.C. (1997), The Econometrics of Financial

Markets; Princeton University Press: New Jersey.

Chatterjea, A. and Jarrow, RA. (1998), Market Manipulation, Price Bubbles, and a Model of the

US Treasury Securities Auction Market; Journal of Financial and Quantitative

Analysis, Vol. 33(2): 255 - 287.

De Zoysa, H.R. (1990), Cash Management; Government Financial Management: Issues and

Country Studies, Premchand, A. (Ed.) International Monetary Fund: Washington D.C.

Department of Finance, (1999), Republic of South Africa: Budget Review.

Fama, E.F. (1975), Short-term Interest Rates as Predictors of Inflation; The American Economic Review, Vol. 65(3:269 - 282), June.

Fama, E.F. (1976), Foundations of Finance: Portfolio Decisions and Security Prices;

Basil Blackwell: Oxford.

Feldman, R. \& Reinhart, V. (1995), Flexible Estimation of Demand Schedules and Revenue under different Auction Formats; International Monetary Fund Working Study, no. 95/116.

Friedman, M. (1959a), Testimany in Employment, Growth, and Price Levels: Hearings before the Joint Economic Committee, $86^{\text {th }}$ Congress, $1^{\text {st }}$ session, 30 October. 
Friedman, M. (1959b), A Program for Monetary Stability; New York: Fordham University Press.

Friedman, M. (1991), How to Sell Gozemment Securities; Wall Street Journal, A8, 1991.

Frost, A.J. \& Hager, D.P. (1990), Debt Securities; Heinemann Professional Publishing Ltd, London.

Gidlow, R.M. (1981), The Market for Treasury Bills in South Africa; The South African Banker, Vol. 78 (1): 26 - 30.

Godbout, L., Storer, P. \& Zimmerman, C. (1999), The Canadian Treasury Bill Auction and the Term Structure of Interest Rates; Working Study, no. 75, Centre for Research on Economic Fluctuations and Employment: University of Montreal.

Goswami, G., Noe, T., \& Rebello, M. (1995), Collusion in Uniform-Price Auctions:

Experimental Evidence and Implications for Treasury Auctions; Working Study No. 95-5, Federal Reserve Bank of Atlanta, September.

Hill, N.C. \& Sartoris, W.L. (1988), Short-Term Financial Management; (New York: Macmillan Publishing Company).

Jegadeesh, N. (1993), Treasury Auction Bids and the Salomon Squeeze; The Journal of Finance, Vol. XIVIII(4): 1403 - 1419, September.

Jordan, B.D. \& Jordan, S.D. (1996), Salomon Brothers and the May 1991 Treasury Auction: Analysis of a Market Comer, Journal of Banking and Finance; Vol. 20, April.

Knoop, H.S. van der, \& Hoijmaans, F.C. (1989), Optimal Allocation of Payments and Receipts; European Journal of Operational Research, Vol. 43, pp161 - 167.

Malvey, P., Archibald, C. \& Flynn, S. (1995), Uniform-price Auctions: Evaluation of the Treasury Experience; Washington D.C.: U.S. Treasury Department.

McAfee, Preston, \& McMillan, J. (1987), Auctions and Bidding; Journal of Economic Literature, Vol. 25: 699 - 738.

Milgrom, P.R. \& Weber, R.J. (1982), A Theory of Auctions and Competitive Bidding; Econometrica, Vol. 50(5): 1089 - 1122, September.

Milgrom, P.R. (1989), Auctions and Bidding: A Primer; Journal of Economic Perspectives; :3 -22 .

Mishkin, F.S. (1982), Monetary Policy and Short-term Interest Rates: An Efficient MarketsRational Expectations Approach; Journal of Finance, Vol. 57(1): 63 - 72, March. Ogden, J.P. (1987), The End of Month as a Preferred Habitat: A Test of Operational Efficiency in the Money Market; Journal of Financial and Quantitative Analysis, Vol. 22(3): 329 343 , September. 
Orgler, Y.E. (1970), Cash Management: Methods and Models; Wardsworth Publishing Company, Inc., Carlifonia.

Palmer, G.F.D. \& Dickman, A.B. (1960), The South African Money Market: Some Further Developments; South African Journal of Economics, : 356 - 357.

Park, S. (1982), Spot and Forreard Rates in the Canadian Treasury Bill Market; Journal of Financial Economics, Vol. 10: 107 - 114.

Park, S.Y. \& Reinganum, M.R. (1986), The Puzzling Behaviour of Bills the Mature at the Tum of Calendar Months; Journal of Financial Economics, Vol. 16: 267 - 283.

Phlips, L. (1995), Competition Policy: A Game-Theoretic Perspective; Cambridge University Press.

Roberts, H. (1967), Statistical versus Clinical Prediction of the Stock Market;

Unpublished Manuscript, University of Chicago, May.

Samuelson, P. (1965), Proof that Property Anticipated Prices Fluctuate Randomb; Industrial Management Review, Vol. 6: 41 - 49.

Samuelson, P. (1972), Mathematics of Speculatize Price; in Day, R., and Robinson, S. (eds.)

Mathematical Topics in Economic Theory and Computation; Society for

Industrial and Applied Mathematics, Philadelphia, PA.

Samuelson, P. (1973), Proof that Properly Discounted Present Values of Assets Vibrate Randomb;

Bell Journal of Economics and Management Science, Vol. 4: 369 - 374.

SARB, (1997a), Discussion Study on Monetary Policy Operational Procedures; October; http://www.resbank.co.za/media/st041297.html

SARB, (1997b), Treasury Bill Tender Procedures; $10^{\text {th }}$ September.

Scheffe, H. (1959), The Analysis of Variance; Wiley: New York.

Schirm, D.C.; Sheehan, R. G.; \& Ferri, M.G. (1989), Financial Market Responses to Treasimy

Debt Annoumcements; Journal of Money, Credit and Banking, Vol. 21(3): 394 - 400, August.

Schoombee (1993), Die Onterkkeling van die Mark wir Statkiwerissels in Suid-Afrika 1980 - 89;

South African Journal of Economics, Vol. 61(3): 177 - 187.

Simon, D.P. (1991), Segmentation in the Treasury Bill Market: Evidence from Cash Management

Bills; Journal of Financial and Quantitative Analysis, Vol. 26(1): 97 - 108, March.

Simon, D.P. (1994a), Further Evidence on Segmentation in the Treasury Bill Market; Journal of Banking and Finance, Vol. 18: 319 - 151. 
Simon, D.P. (1994b), The Treasmy's Experiment with Single Price Auctions in the Mid-1970s:

Wrmer's or Taxpayer's Curse?; Review of Economics and Statistics, Vol. 76(4): 754

- 760, November.

Tenorio, R. (1993), Revernue Equizalence and Bidding Behaviour in a Multi-Unit Auction Market: An Empirical Analysis; Review of Economics and Statistics, Vol. 75: 302 - 317.

Umlauf, S.R. (1993), An Empirical Study of the Mexican Treasury Bill Auction; Journal of Financial Economics, Vol. 33: 313 -340.

Van Der Knoop, H. (1996), Casb Management Optimisation by the Dutch Central Goverment; Public Finance, Vol. 5(1): 33 - 53.

Wall, J.P. (1973), Aspects of Short-term Money Market in South Africa; The Investment Analysts Journal, November, : 19.

Wilson, R. (1975), Investing the Treasury's Money; Federal Reserve bank of San Francisco: Research Department, June 27.

Wilson, R. (1977), Managing the Public's Cash; Federal Reserve bank of San Francisco: Research Department, October 21. 


\begin{tabular}{|c|c|c|}
\hline $\begin{array}{c}\text { Revenue Estlmation } \\
\text { Committee (SARS, } \\
\text { Budget Offlce, } \\
\text { SARB) }\end{array}$ \\
\hline $\begin{array}{c}\text { Determine and } \\
\text { revise annual } \\
\text { projections }\end{array}$ \\
\hline $\begin{array}{c}\text { Annual } \\
\text { projection }\end{array}$
\end{tabular}$\rightarrow$\begin{tabular}{l}
$\begin{array}{c}\text { Directorate: Cash } \\
\text { Management }\end{array}$ \\
\hline $\begin{array}{l}\text { Compile provisional } \\
\text { monthly cash-flow } \\
\text { statement (own } \\
\text { projections) }\end{array}$ \\
\hline $\begin{array}{c}\text { Annual } \\
\text { projectlons }\end{array}$ \\
\hline
\end{tabular}
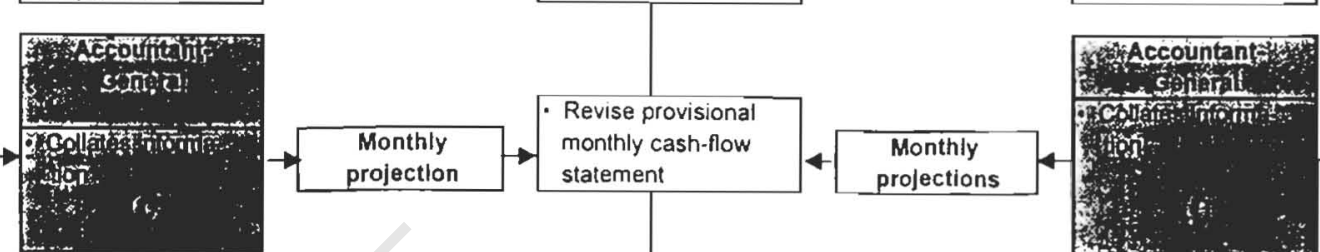

\begin{tabular}{|l|l|l|}
\hline $\begin{array}{c}\text { State Expenditure } \\
\text { (expenditure } \\
\text { control) }\end{array}$ & $\begin{array}{l}\text { Government } \\
\text { Departments }\end{array}$ \\
\cline { 1 - 1 } $\begin{array}{l}\text { - Approve monthly } \\
\text { allocations for fiscal } \\
\text { year }\end{array}$ & $\begin{array}{l}\text { Provide monthly } \\
\text { projections }\end{array}$ \\
\hline
\end{tabular}

\begin{tabular}{|c|}
\hline SARS \\
\hline $\begin{array}{c}\text { Provide input } \\
\text { (15th of each } \\
\text { month) }\end{array}$ \\
\hline
\end{tabular}
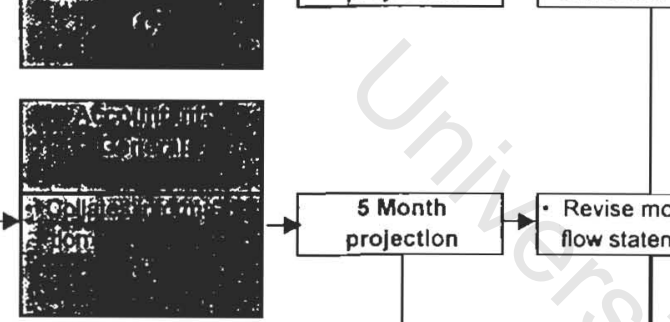

\begin{tabular}{|c|}
\hline \multicolumn{1}{|c|}{ SARS } \\
\hline $\begin{array}{l}\text { Provide input } \\
\text { (15th of each } \\
\text { month and revised } \\
\text { When needed) }\end{array}$ \\
\hline
\end{tabular}
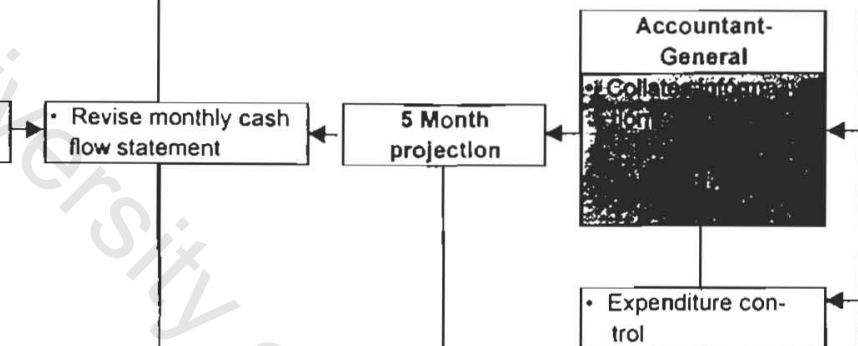

Government Departments Provide projections: - months 1 and 2 on weekly basis - months 3.4 and 5 on monthly basis

Government Requisition money
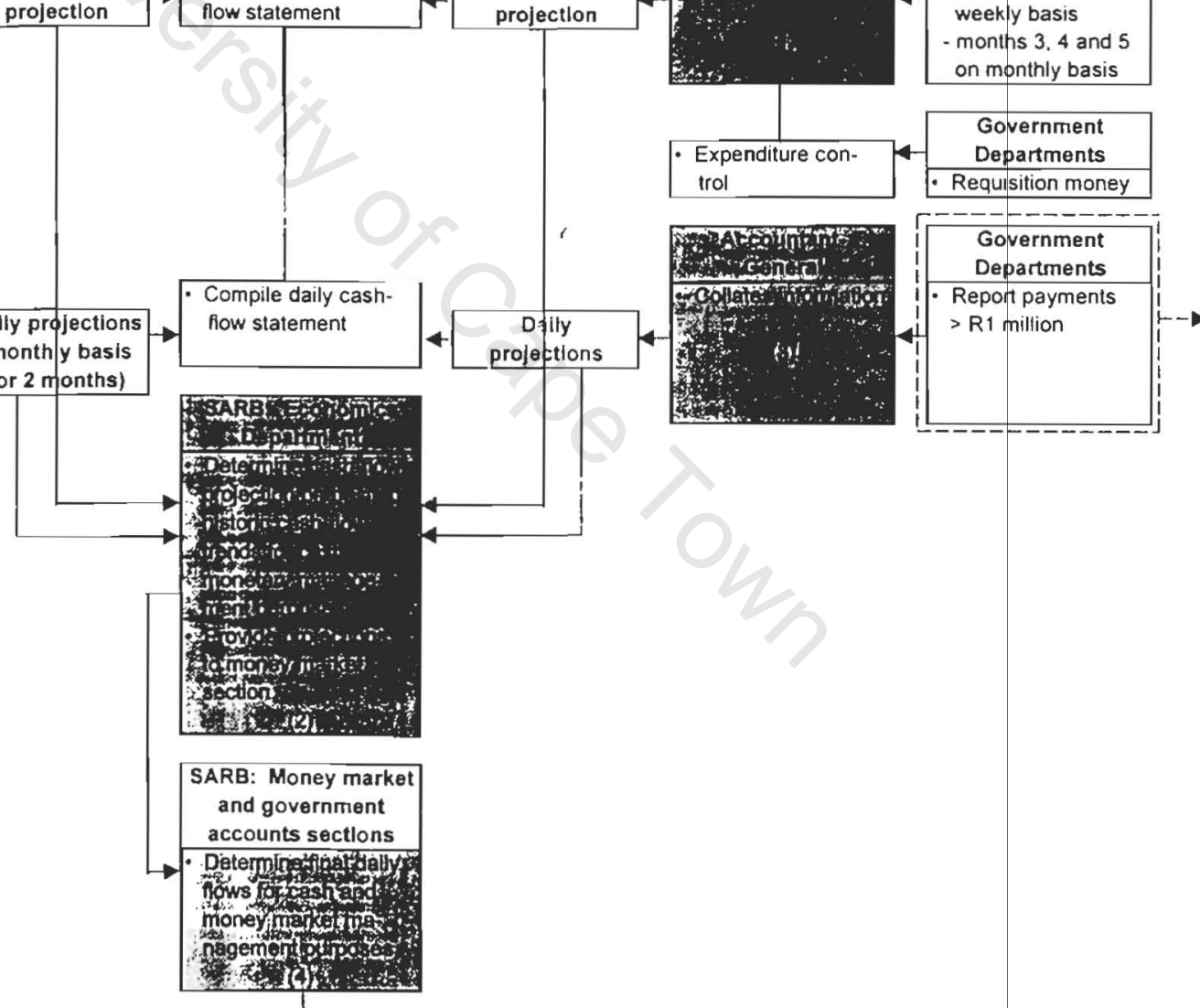

Prepare projections for

money market meetings 


\section{Appendix 2: Effect of international prices on domestic prices}

\section{First sub-sample (1980Q2-1989Q4)}

Co-integration test

Date: 07/14/99 Time: 02:42

Sample: 1980Q2 1989Q4

Included observations: 27

Test

assumption:

Linear

deterministic

trend in the

data

Series: DUSPPOWEREND DPPOWEREND

Lags interval: 1 to 1

\begin{tabular}{ccccc}
\hline \hline Eigenvalue & $\begin{array}{c}\text { Likelihood } \\
\text { Ratio }\end{array}$ & $\begin{array}{c}\text { 5-percent } \\
\text { Critical Value }\end{array}$ & $\begin{array}{c}\text { 1-percent } \\
\text { Critical Value }\end{array}$ & $\begin{array}{c}\text { Hypothesized } \\
\text { No. of CE(s) }\end{array}$ \\
\hline \hline 0.576765 & 29.22658 & 15.41 & 20.04 & None $^{\star \star}$ \\
0.199596 & 6.011242 & 3.76 & 6.65 & At most 1 \\
\hline \hline
\end{tabular}

${ }^{\star}\left({ }^{\star \star}\right)$ denotes

rejection of the

hypothesis at

$5 \%(1 \%)$

significance

level

L.R. test

indicates 2

cointegrating

equation(s) at

$5 \%$

significance

level

Unnormalized Cointegrating Coefficients:

\begin{tabular}{cc}
\hline \hline DUSPPOWER DPPOWEREN \\
END & D \\
57.39350 & 16.61874 \\
-15.85065 & 26.68079 \\
\hline \hline
\end{tabular}

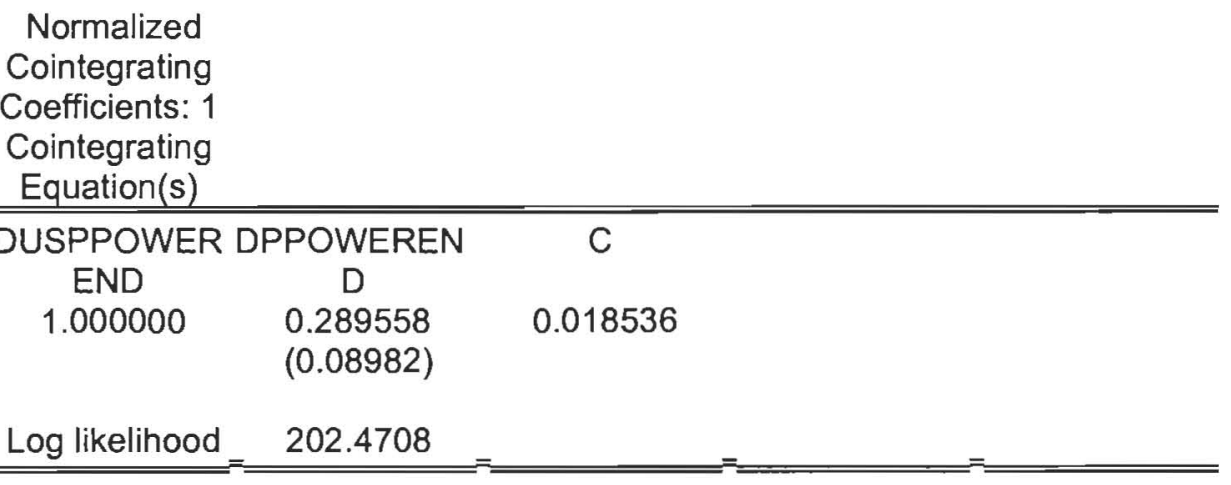

Cross-comelations of US and $S A$ changes in purchasing power

Date: 07/14/99 Time:

$$
02: 43
$$

Sample: 1980Q2 1989Q4

Included observations: 29 


\begin{tabular}{|c|c|c|c|}
\hline $\begin{array}{c}\text { DUSPPOWEREND,DPP } \\
\text { OWEREND }(-i) \\
\end{array}$ & $\begin{array}{c}\text { DUSPPOWEREND,DPP } \\
\text { OWEREND }(+i) \\
\end{array}$ & i lag & lead \\
\hline 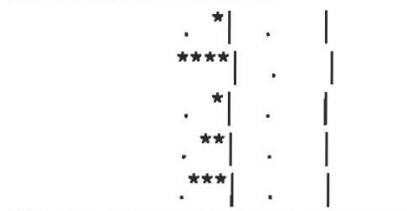 & \begin{tabular}{ll|}
$\cdot{ }^{*} \mid$ & $\mid$ \\
$\cdot{ }^{* \star} \mid$ & $\mid$ \\
$\left.\cdot\right|^{\star \star} \cdot$ & $\mid$ \\
$\cdot \mid$ & $\mid$
\end{tabular} & $\begin{array}{ll}0 & -0.0615 \\
1 & -0.3668 \\
2 & -0.0514 \\
3 & -0.1490 \\
4 & -0.3047\end{array}$ & $\begin{array}{r}-0.0615 \\
-0.0385 \\
-0.1507 \\
0.2330 \\
-0.0016\end{array}$ \\
\hline
\end{tabular}

\section{Second sub-sample (1990Q1-1998Q4)}

\section{Co-integration}

Date: 07/14/99 Time: 02:47

Sample: 1990Q1 1998Q4

Included observations: 36

Test

assumption:

Linear

deterministic

trend in the

data

Series: DUSPPOWEREND DPPOWEREND

Lags interval: 1 to 1

\begin{tabular}{|c|c|c|c|c|}
\hline Eigenvalue & $\begin{array}{c}\text { Likelihood } \\
\text { Ratio } \\
\end{array}$ & $\begin{array}{c}\text { 5-percent } \\
\text { Critical Value }\end{array}$ & $\begin{array}{c}1 \text {-percent } \\
\text { Critical Value } \\
\end{array}$ & $\begin{array}{l}\text { Hypothesized } \\
\text { No. of CE(s) }\end{array}$ \\
\hline $\begin{array}{l}0.267504 \\
0.141615 \\
\end{array}$ & $\begin{array}{l}16.70400 \\
5.497308 \\
\end{array}$ & $\begin{array}{r}15.41 \\
3.76 \\
\end{array}$ & $\begin{array}{r}20.04 \\
6.65 \\
\end{array}$ & $\begin{array}{c}\text { None }{ }^{*} \\
\text { At most } 1 \text { * }\end{array}$ \\
\hline $\begin{array}{c}\left.{ }^{*}{ }^{\star \star}\right) \text { denotes } \\
\text { rejection of th } \\
\text { hypothesis at } \\
5 \%(1 \%) \\
\text { significance } \\
\text { level } \\
\text { L.R. test } \\
\text { indicates } 2 \\
\text { cointegrating } \\
\text { equation(s) a } \\
5 \% \\
\text { significance } \\
\text { level }\end{array}$ & & & & \\
\hline \multicolumn{5}{|c|}{ Unnormalized Cointegrating Coefficients: } \\
\hline $\begin{array}{c}\text { DUSPPOWEP } \\
\text { END } \\
-45.16284 \\
50.95095\end{array}$ & $\begin{array}{c}\text { PPOWERE } \\
\text { D } \\
25.29865 \\
1.834029\end{array}$ & & & \\
\hline
\end{tabular}

Normalized

Cointegrating

Coefficients: 1

Cointegrating

Equation(s)

\begin{tabular}{ccc} 
& \\
\hline \hline DUSPPOWER DPPOWEREN & $\mathrm{C}$ \\
END & $\mathrm{D}$ & \\
1.000000 & -0.560165 & -0.006209 \\
& $(0.18549)$ &
\end{tabular}


Cross-correlations of US and SA changes in purchasing power

Date: 07/14/99 Time:

$02: 48$

Sample: 1990Q1 1998Q4

Included observations: 36

Correlations are asymptotically consistent approximations

\begin{tabular}{|c|c|c|c|c|}
\hline $\begin{array}{c}\text { DUSPPOWEREND,DPP } \\
\text { OWEREND }(-i)\end{array}$ & $\begin{array}{c}\text { DUSPPOWEREND,DPP } \\
\text { OWEREND }(+i) \\
\end{array}$ & $\mathrm{i}$ & lag & lead \\
\hline$\left.\cdot\right|^{\star \star \star \star} \mid$ & $\left.\cdot\right|^{\star \star \star \star} \mid$ & 0 & 0.4311 & 0.4311 \\
\hline$\left.\right|^{\star}$. & $\left.\right|^{\star \star \star}$ & 1 & 0.0822 & 0.2830 \\
\hline |* &.$\left.\right|^{\star \star \star}$ & 2 & 0.1057 & 0.2664 \\
\hline$\left.\right|^{\star \star}$. &.$\left.\right|^{\star \star \star}$ & 3 & 0.1946 & 0.2573 \\
\hline$\left.\right|^{*}$. & $\left.\right|^{\star \star *}$. & 4 & 0.1359 & 0.2190 \\
\hline
\end{tabular}

Regression results for market efficiency using US prices

Dependent Variable: DPPOWEREND

Method: Least Squares

Date: 07/15/99 Time: 02:18

Sample(adjusted): 1990Q1 1998Q3

included observations: 35 after adjusting endpoints

\begin{tabular}{lrlrr}
\hline \hline \multicolumn{1}{c}{ Variable } & Coefficient & Std. Error & t-Statistic & Prob. \\
\hline \hline C & 0.001530 & 0.009450 & 0.161862 & 0.8724 \\
$\quad$ NRETURNEND & -0.609187 & 0.268112 & -2.272137 & 0.0299 \\
DUSPPOWEREND(- & 0.375424 & 0.431985 & 0.869068 & 0.3913 \\
\multicolumn{1}{c}{ 1) } & & & & \\
\hline \hline R-squared & 0.212774 & Mean dependent var & -0.024137 \\
Adjusted R-squared & 0.163572 & S.D. dependent var & 0.010611 \\
S.E. of regression & 0.009705 & Akaike info criterion & -6.350556 \\
Sum squared resid & 0.003014 & Schwarz criterion & -6.217241 \\
Log likelihood & 114.1347 & F-statistic & 4.324530 \\
Durbin-Watson stat & 1.636589 & Prob(F-statistic) & 0.021757 \\
\hline \hline
\end{tabular}

Wald test

Wald Test:

Equation: Untitled

\begin{tabular}{|c|c|c|c|}
\hline Null Hypothesis: & $\begin{array}{l}C(2)=-1 \\
C(3)=0\end{array}$ & & \\
\hline $\begin{array}{l}\text { F-statistic } \\
\text { Chi-square }\end{array}$ & $\begin{array}{l}1.121275 \\
2.242551\end{array}$ & $\begin{array}{l}\text { Probability } \\
\text { Probability }\end{array}$ & $\begin{array}{l}0.338331 \\
0.325864\end{array}$ \\
\hline
\end{tabular}

Residual autocomrelations

Date: 07/15/99 Time: 02:20

Sample: 1990Q1 1998Q3

Included observations: 35

\begin{tabular}{|c|c|c|c|c|c|c|}
\hline Autocorrelation & Partial Correlation & & $\mathrm{AC}$ & PAC & Q-Stat & Prob \\
\hline . $\left.\right|^{\star}$ & |* & 1 & 0.136 & 0.136 & 0.7073 & 0.400 \\
\hline & |* & 2 & 0.183 & 0.168 & 2.0270 & 0.363 \\
\hline$\left.\right|^{\star \star}$. & |* & 3 & 0.202 & 0.166 & 3.6847 & 0.298 \\
\hline & & 4 & 0.019 & -0.052 & 3.7005 & 0.448 \\
\hline
\end{tabular}




\section{End Notes}

i Saddle point - A stable solution to a game where participants have dominating strategies and the resulting solution makes none of them to have an incentive to change the strategy unilaterally, unless at a loss.

ii Pareto efficiency - A situation where parties to a game or a bargaining system benefit without making any of them worse off.

iii Dominant strategy - A strategy superior to any of the alternative strategies in all respects. Other strategies to the game may therefore be deleted or disregarded in trying to locate a saddle point.

iv Common value assumption - An assumption that participants to the auction have common knowledge regarding the value of the object at the point of sale but they do not know the price for which it will be resold. For instance, a bond can have a face value of R100 known to everybody, but they may not know whether it will be sold for R96 or R97.

v Winner's curse - A situation where the winner to the auction finds that the price for which they acquired the object is higher than its subsequent resale price, which therefore results in a loss.

vi Martingale process - Process whereby the expected value of a variable is constant or the same over time.

vii Bandwagon effect - A situation where one party to a game makes a decision and the rest of the participants follow the same decision. This is usually to avoid a situation where one loses alone whereas the average participant wins. 